UDK: 343.264::(=497.6)]:(497.6Bosanska krajina) Pregledni članak

Primljeno: 15. 4. 2021.

Prihvaćeno za štampu: 11. 11. 2021.

Dr. sc. Mujo Begić

Docent na Univerzitetu u Bihaću, Islamski pedagoški fakultet Bihać mujo_begi@hotmail.com

Mr. sc. Ermin Vučkić

Medžlis IZ Ključ

erminvuckic@yahoo.com

\title{
NASILNI PROGON I PRISILNE DEPORTACIJE BOŠNJAKA S PODRUČJA BOSANSKE KRAJINE KAO REZULTAT PROGLAŠENJA REPUBLIKE SRPSKOG NARODA U BOSNI I HERCEGOVINI
}

\section{Sažetak}

Rezultat proglašenja i djelovanja Republike srpskog naroda u Bosni i Hercegovini je agresija i genocid koje su počnili srpske vojne i policijske snage nad Bošnjacima. Srpski agresor je u agresiju na Republiku Bosnu i Hercegovinu uz koristenje nadmónije vojne sile, civile i civilno stanovnistvo ubijao, ranjavao, razarao njibovu imovinu, prisilno progonio iz njihovih domova i prisiljavao it da trajno napuste svoje domove i imovinu. Prisilna premještanja i deportacije Bošnjaka i Hrvata s prostora Bosanske krajine bile su masovne, sistematicne i planirane, a praćene su ubijanjima, nasiljem, raznim prinudama, nezakonitim zatočenjima, silovanjima, miniranjem $i$ paljenjem kuća, pljačkom imovine, psibickeim pritiscima od strane srpskih vojnih i policijskih jedinica $i$ civilnih vlasti. Cilj ovih progona i deportacija bio je ostanak 2\% nesrpskog stanovnistva na teritoriji Bosanske krajine. U periodu 1992-1995. godine više stotina hiljada građana nesrpske nacionalnosti s prostora Bosanske krajine je prisilno protjerano

Ključne riječi: agresija, genocid, Bosanska krajina, progon, deportacije.

\section{Uvod}

U agresiji na Republiku Bosnu i Hercegovinu na identičan način, po istom modelu, kao u agresiji na Republiku Hrvatsku uz korištenje 
nadmoćnije vojne sile, srpske vojne i policijske snage su civile i civilno stanovništvo ubijali, ranjavali, razarali njihovu imovinu, prisilno progonili iz njihovih domova i prisiljavali da trajno napuste svoja domove i imovinu. ${ }^{1}$ Do sada su kao neosporne, naučno i sudski potvrđene "dvije početne i osnovne, bitne i fundamentalne postavke i odredbe savremenih događanja i događaja u Republici Bosni i Hercegovini na kraju XX stoljeća: prvo, na Republiku Bosnu i Hercegovinu izvršena je klasična oružana agresija, odnosno zločin protiv mira i sigurnosti čovječanstva, što je po osnovnom shvatanju i definiciji međunarodni oružani sukob, i drugo, na okupiranim područjima nezavisne i međunarodno priznate Republike Bosne i Hercegovine, članice Ujedinjenih nacija, kao i u gradovima u opsadi, nad Bošnjacima je izvršen najteži zločin - zločin genocida."2

Prema relevantnim podacima iz svojih domova nasilno je protjerano "oko 2.200.000 osoba (1.170.000 su izbjeglice i oko 1.030 .000 raseljena lica), što čini više od jedne polovine ukupnog stanovništva Republike Bosne i Hercegovine po popisu stanovništva iz 1991. godine. “3

Prema odredbama Ženevske konvenciji o zaštiti građanskih osoba za vrijeme rata od 12. augusta 1949. godine, član 49. i Dopunskog protokola uz Ženevske konvencije od 12. augusta 1949. godine o zaštiti žrtava nemeđunarodnih oružanih sukoba - Protokol II, član 17, zabranjuje se prisilno premještanje civila ako to ne zahtijevaju sigurnosni razlozi. ${ }^{4}$

${ }^{1}$ Begić, M., 2017. Genocid u Sanskom Mostu, Institut za istraživanje zločina protiv čovječnosti i međunarodnog prava Univerziteta u Sarajevu, Sarajevo, 2017. str. 752.

2 Čekić, S., 2012. Genocid $i$ istina o genocidu u Bosni $i$ Hercegovini, Institut za istraživanje zločina protiv čovječnosti i međunarodnog prava Univerziteta u Sarajevu, Sarajevo, str. 17.

3 Čekić, S., 2007. Genocid u Bosni i Hercegovini na kraju dvadesetog stoljeća, uvodni referat na VII bijenalnoj konferenciji Pravovremeno reagovanje na genocid: istraživanje genocida i njegova prevencija, Sarajevo, 9-13. jula 2007. str. 7.

${ }^{4}$ U članu 49. Konvencije navodi se: "Prinudna preseljavanja, masovna ili pojedinačna, kao i progonstva zaštićenih osoba izvan okupirane teritorije na teritoriju okupirajuće Sile ili na teritoriju koje bilo druge države, okupirane ili ne, zabranjena su, bez obzira na razlog. Ipak, okupirajuća Sila može da pristupi potpunoj ili djelimičnoj evakuaciji mogu sobom povući preseljenje zaštićenih osoba samo u unutrašnjost okupirane 
Prisilna premještanja i deportacije kao zabranjena djela definisana su Statutom Međunarodnog krivičnog suda za bivšu Jugoslaviju (dalje: MKSJ). U predmetu MKSJ protiv Momčila Krajišnika bliže se opisuje ovo krivično djelo. Tako se navodi: "I deportacija $i$ prisilno premještanje podrazumijevaju prisilno raseljavanje osoba s područja na kojem se one zakonito nalaze, bez osnova dopuštenih međunarodnim pravom. Uslov za zločin deportacije jeste da žrtve budu raseljene preko državne granice de jure ili, u određenim situacijama, granice de facto. Prisilno premještanje uključuje raseljavanje osoba unutar državnih granica." Prisilno raseljavanje podrazumijeva da ljudi budu raseljeni protiv svoje volje ili bez stvarne mogućnosti izbora. Strah od nasilja, prinude, zatočenja, psihički pritisak i druge slične okolnosti mogu stvoriti atmosferu u kojoj alternativa odlasku ne postoji, odnosno mogu predstavljati prisilno raseljavanje ljudi. ${ }^{6}$

Šta je bio cilj prisilnih progona i deportacije nesrpskog stanovništva s prostora koji su bili okupirani od strane srpskih vojnih i policijskih snaga? U predmetu MKSJ protiv Slobodana Miloševića navodi se: "I Radovan Karadžić i Biljana Plavšić izjavili su da je osnovni cilj rata koji vode Srbi preraspodela stanovništva Bosne i Hercegovine kako bi Srbima pripala kontrola nad jedinstvenim povezanim komadom teritorije, koji bi obuhvatio čitavu granicu sa Crnom Gorom, Srbijom $i$ sva područja na kojima istorijski žive Srbi (podvukao, M. B). Zbog toga

teritorije, izuzev u slučaju materijalne nemogućnosti. Stanovništvo koje je na taj način evakuisano ima biti vraćeno u svoje domove čim neprijateljstva na tome području prestanu. Pristupajući tim preseljenjima ili tim evakuacijama, okupirajuća Sila je dužna postarati se, u najvećoj mogućoj mjeri, da zaštićene osobe budu pristojno smještena, da se preseljenja izvrše pod zadovoljavajućim uslovima u pogledu zdravlja, higijene, sigurnosti i ishrane, kao i da članovi jedne iste porodice ne budu odvajani jedni od drugih. Sila zaštitnica ima se obavijestiti o preseljenjima i evakuaciji čim do njih dođe. Okupirajuća Sila ne smije da zadržava zaštićene osobe u oblasti koja je naročito izložena ratnim opasnostima, izuzev ako to zahtijeva sigurnost stanovništva ili imperativni vojni razlozi. Okupirajuća Sila ne smije da pristupi deportovanju niti preseljenju određenog dijela svog vlastitog stanovništva na teritorij koji je okupirala." Zbirka propisa, Međunarodne konvencije o ratnom pravu $i$ sigurnosti, ZONO, Zagreb, 1979. str. 155 i 247.

5 ICTY, Predmet br. IT-00-39-T, PRED PRETRESNIM VIJEĆEM I, TUŽILAC PROTIV MOMČILA KRAJIŠNIKA, PRESUDA, 27. septembar 2006. paragraf 723.

${ }^{6}$ Isto, paragraf 724. 
je trebalo ukloniti veliki broj bosanskih Muslimana jer su oni bili većinsko stanovništvo u dolini Drine u severoistočnoj Bosni, uz granicu sa Srbijom."7

Pripreme za realizaciju projekta nasilnog progona počinju sa stvaranjem paralelnih i protivustavnih srpskih zajednica (Republika srpskog naroda u Bosni i Hercegovini, Srpske autonomne oblasti i srpske opštine). Prva paralelna regionalna zajednica osnovana na prostoru sjeverozapadne Bosne bila je Zajednica opština Bosanske krajine (dalje: ZOBK-a). Jedan od razloga za ovaj potez vidljiv je u presudi MKSJ-a u predmetu Milomir Stakić, gdje se navodi: “očekujući da će se Bosna i Hercegovina otcijepiti od Jugoslavije, rukovodstvo bosanskih Srba je već u aprilu 1991. godine oformilo Zajednicu opština Bosanske Krajine, koju su činili predstavnici opština s većinskim srpskim stanovništvom. "8 Inicijativa za osnivanje Zajednice opština dobila je podršku SDS-a na sastanku Regionalnog odbora SDS-a održanog 7. aprila 1991. godine, čime je zvanično otpočelo osnivanje ZOBK-a. Pripreme za osnivanje ZOBK-a počele su tokom aprila 1991. godine, da bi 25. aprila 1991. godine, u hotelu Turist u Čelincu, bila održana Osnivačka skupština. Na Skupštini su bili prisutni predstavnici 21 opštine, iako je samo 14 predstavnika opština glasalo za udruživanje u zajednicu.

Osnivači ZOBK-a postigli su Dogovor o udruživanju u Zajednicu opština Bosanske krajine (dalje: Dogovor). ${ }^{9}$ Dogovor je postiglo 20 opština. Kao sjedište ZOBK-a izabrana je Banja Luka. Nakon osnivanja ZOBK-a i u drugim dijelovima počinje proces formiranja ovih neustavnih kategorija.

Skupština ZOBK-a, 16. septembra 1991. godine, na svojoj 7. sjednici, donijela je odluku o transformaciji ZOBK-a u Autonomnu regiju Krajina (dalje: ARK). U toj odluci o transformisanju objavljuje se

7 ICTY, Predmet br. IT-02-54-T, TUŽILAC PROTIV SLOBODANA MILOŠEVIĆA, ODLUKA PO PRIJEDLOGU ZA DONOŠENJE OSLOBAĐAJUĆE PRESUDE, 16. juni 2004. paragraf 238.

8 ICTY, PREDMET IT-97-24, PRED PRETRESNIM VIJEĆEM, TUŽILAC PROTIV MILOMIRA STAKIĆA, PRESUDA, 31. juli 2003. paragraf 32.

${ }^{9}$ AIIZ, inv. br. 2-4983, DOGOVOR O UDRUŽIVANJU U ZAJEDNICU OPŠTINA BOSANSKE KRAJINE. 
osnivanje ARK-a kao "neodvojivog dijela Savezne države federativne Jugoslavije i sastavnog dijela Federativne jedinice BiH. Istog dana je usvojen i Statut ARK-a, koji je bio gotovo identičan Statutu ZOBK-a. Sjedište ARK-a, kao i ZOBK-a, bilo je u Banjoj Luci“. ${ }^{10}$

Slijedom ovih “(...) paraustavnih kategorija",11 jer Ustav SR BiH autonomne oblasti ne poznaje kao političko-teritorijalne organizacije niti teritorijalne etničke ekskluzivitete, "ujesen 1991, u SR BiH su osnovane još četiri srpske autonomne oblasti. To su bile Srpska Autonomna Oblast Hercegovina, Srpska Autonomna Oblast Romanija, Birač, Srpska Autonomna Oblast Semberija i Srpska Autonomna Oblast Sjeverna Bosna“.12 Skupština Srpske republike BiH 21. novembra donijela je Odluku o verifikaciji proglašenih srpskih oblasti u Bosni $i$ Hercegovini ${ }^{13}$ kao nedvojbenih dijelova savezne države, federativne Jugoslavije, i sastavnih dijelova federalne jedinice Bosne i Hercegovine, kao i izdvajanje naseljenih mjesta iz jedne opštine i uključivanje u sastav druge opštine.

Politička situacija u Bosni i Hercegovini dodatno se usložnjavala kada je Skupština srpskog naroda u Bosni i Hercegovini donijela odluku o ostajanju srpskog naroda u zajedničkoj državi sa Srbijom i Crnom Gorom i drugim srpskim paradržavnim oblastima u Republici Hrvatskoj. ${ }^{14}$ Ovim je u praksi otpočeo projekt zaokruživanja velike Srbije. Reagirajući na ovakav akt konstituisanja, "Zakonodavnopravna

10 ICTY, PREDMET IT-99-36-T, PRED PRETRESNIM VIJEĆEM, TUŽILAC PROTIV RADOSLAVA BRĐANINA, PRESUDA, 1. septembar 2004. godine, paragraf 166.

${ }^{11}$ Begić, K., 1997. Bosna i Hercegovina od Vensove misije do Dejtonskog sporazuma, Bosanska knjiga, Sarajevo, str. 59.

12 ICTY, PREDMET IT-99-36-T, PRED PRETRESNIM VIJEĆEM, TUŽILAC PROTIV RADOSLAVA BRĐANINA, PRESUDA, 1. septembar 2004. godine, paragraf 167.

13 ODLUKA O VERIFIKACIJI PROGLAŠENIH SRPSKIH OBLASTI U BOSNI I HERCEGOVINI, broj 37-02/91 od 21. novembra 1991. objavljeno u: Službeni glasnik srpskog naroda u $\mathrm{BiH}$, br. I/92, od 15. januara 1992. str. 8.

${ }^{14}$ ODLUKA O OSTAJANJU SRPSKOG NARODA BOSNE HERCEGOVINE U ZAJEDNIČKOJ DRŽAVI JUGOSLAVIJI, broj 02-17/91, od 24. oktobra 1991. objavljeno u: Službeni glasnik srpskog naroda u BiH, br. I/92, od 15. januara 1992. str. 1. 
komisija Skupštine SR BiH ocijenila je da je ovakav čin nelegitiman, jer po Ustavu SR BiH, izbornim zakonima i Poslovnikom Skupštine, zastupnici u Skupštini SR BiH nisu legitimni predstavnici svog naroda, nego predstavnici građana - birača izborne jedinice u kojoj su ih građani, a ne narodi birali, pa time i nemaju mandat da predstavljaju i zastupaju jedan od naroda iz te izborne jedinice“. ${ }^{15}$ Nastavljajući kontinuitet destrukcije $\mathrm{SR} \mathrm{BiH}$, održan je plebiscit srpskog naroda novembra 1991. godine, ${ }^{16}$ koji je u osnovi bio opravdanje za proglašenje Srpske republike. ${ }^{17}$ Proces derogiranja SR BiH predstavnici Skupštine Srpske republike BiH nastavili su donošenjem Ustava 28. februara 1992. godine. ${ }^{18}$

Proces stvaranja srpskih autonomnih oblasti, a kasnije i Republike srpskog naroda u BiH, predstavlja najgrublji oblik narušavanja ustavnih principa, ravnopravnosti građana, principa da su građani nosioci vlasti, teritorijalnog jedinstva i nedjeljivosti $\mathrm{BiH}$, što je u direktnoj suprotnosti s odredbama Ustava SR BiH (amandmani LX, LXII, LXVII na Ustav SR BiH). ${ }^{19}$ Možemo sa sigurnošću reći da je glavni zadatak stvaranje pararegionalnih i paradržavnih tvorevina srpskog naroda $\mathrm{u} \mathrm{BiH}$ oblikovanje zacrtanog etničkog prostora koji je trebalo pripojiti velikoj Srbiji. U prilog ovoj tvrdnji ide Deklaracija o državnom i političkom uređenju Republike srpskog naroda ${ }^{20}$ kao ekskluziviteta jednog naroda (srpskog), što će se u praksi pokušati ostvariti provođenjem genocidne politike i etničkog čišćenja u periodu 1992-1995. godine.

Politika SDS-a na homogenizaciji i teritorijalnom spajanju prostora na kojima žive Srbi produžena je na opštine koje su gravitirale srpskim autonomnim oblastima, ako su dijelovi tih opština nastanjeni srpskim stanovništvom i ako postoji prirodna komunikacija $s$ već homogeniziranim srpskim prostorom. Ova politika našla je svoj pravni

\footnotetext{
${ }^{15}$ Begić, 1997. str. 61.

${ }^{16}$ Službeni glasnik srpskog naroda u BiH, br.1/92.

${ }^{17}$ Službeni glasnik srpskog naroda u BiH, br. 2/92.

${ }^{18}$ Službeni glasnik srpskog naroda u BiH, br. 3/92.

${ }^{19}$ Službeni list SRBiH, br. 21/90.

${ }^{20}$ DEKLARACIJA SKUPŠTINE SRPSKOG NARODA U BOSNI I HERCEGOVINI, objavljeno u: Službeni glasnik srpskog naroda u BiH, br. I/92, od 15. januara 1992. str. 7.
} 
odraz u Odluci o teritorijama opština, mjesnih zajednica $i$ naseljenih mjesta $u$ BiH, koja se smatraju teritorijom Savezne države Jugoslavije, ${ }^{21}$ koju je donijela Skupština srpskog naroda u BiH, 21. novembra 1991. godine. Prostor Bosanske krajine svojom geostrateškom pozicijom predstavljao je smetnju u povezivanju teritorija tzv. SAO Krajine u veliku Srbiju i stoga se moralo pristupiti rješavanju ovog problema.

$\mathrm{Na}$ prostoru Bosanske krajine došlo je do proglašenja i formiranja srpskih opština. Tako su osnovane srpske opštine Bihać (28. decembra 1991. godine), Bosanska Krupa (25. oktobra 1991. godine) Ključ (16. januara 1992. godine), Bosanski Petrovac (22. maja 1992. godine), Sanski Most (25. marta 1992. godine) i Prijedor (7. januar 1992. godine).

Konačno, donošenjem šest strateških ciljeva srpskog naroda u Bosni i Hercegovini (16. sjednica Skupšine srpskog naroda u Bosni i Hercegovini održana 12. maja 1992. godine) izvršene su priprema za realizaciju projekta nasilnog i nazakonitog progona nesrpskog stanovništva.

\section{Nasilni progon i prisilne deportacije Bošnjaka i Hrvata s područja Bosanske krajine kao dio ratne strategije}

Prisilni progon i deportacija Bošnjaka i Hrvata s prostora Bosanske krajine bila su masovna, sistematična i planirana. Nije se radilo o izoliranim i pojedinačnim slučajevima nego smišljenom i planiranom projektu. ${ }^{22}$ U ovaj projekat su uključene sve opštine koje su "pripadale" Autonomnoj regiji Krajina (dalje: ARK) a u kojima su živjeli Bošnjaci i Hrvati. Glavni cilj progona i deportacija je izražen u izjavi Radoslava Brđanina, predsjednika Skupštine ARK-a, koji kaže da je prihvatljiv postotak nesrba u srpskoj državi oko $2 \% .^{23}$

\footnotetext{
${ }^{21}$ Odluka o teritorijama opština, mjesnih zajednica i naseljenih mjesta u BiH koje se smatraju teritorijama Savezne države Jugoslavije, objavljeno u: Službeni glasnik srpskog naroda u BiH, br. I/92, od 15. januara 1992. godine, str. 7.

22 Begić, 2017. str. 752.

23 ICTY, Predmet br. IT-94-1-T, PRED PRETRESNIM VIJEĆEM, TUŽILAC PROTIV DUŠKA TADIĆA, MIŠLJENJE I PRESUDA, 7. maj 1997. paragraf 147.
} 
U presudi MKSJ u predmetu Radoslav Brđanin ovaj stav se potvrđuje: "Pretresno vijeće se van razumne sumnje uvjerilo da su se protjerivanja i prisilna premještanja sistematski provodila u cijelom ARK-u, u kojem $i$ iz kojeg su trajno raseljene desetine hiljada bosanskih Muslimana $i$ bosanskih Hrvata, $i$ da je cilj tog masovnog prisilnog raseljavanja bilo etničko čišćenje tog područja (podvukao M. B.). Za te ljude jedini izbor bio je bijeg. Vlasti bosanskih Srba su onima koje nisu protjerali, a koji nisu uspjeli da pobjegnu, nametnuli nepodnošljive životne uslove, u kojima je bilo nemoguće nastaviti živjeti i koji su ih primorali da traže dozvolu za odlazak. Bosanskim Muslimanima i bosanskim Hrvatima bilo je ograničeno kretanje i živjeli su izloženi opasnosti. Od njih se tražilo da potpišu izjavu o lojalnosti vlastima bosanskih Srba i, u najmanje jednom slučaju, da nose bijelu traku oko ruke. Otpuštani su s posla i oduzimano im je zdravstveno osiguranje. Pokrenuta je kampanja organizovanog zastrašivanja usmjerena naročito na bosanske Muslimane i bosanske Hrvate."24

Da su preseljenja i deportacije bile mimo volje onih koji su morali napustiti svoja ognjišta i da su vršena na prisilan način utvrdio je MKSJ u presudi u predmetu Radoslav Brđanin. U presudi je navedeno: "Na osnovu dokaza koje je imalo pred sobom, Pretresno vijeće se stoga van razumne sumnje uvjerilo u to da su raseljavanje bosanskih Muslimana i bosanskih Hrvata (tj. deportacija i prisilno premještanje) i navodno dobrovoljan odlazak nekih od njih, unutar ARK-a i iz ARK-a, u stvari bili prisilni (podvukao M. B.)." 25

Prisilna raseljavanja i deportacije na području opština Bosanske krajine praćeni su ubijanjima, nasiljem, raznim prinudama, nezakonitim zatočenjima, silovanjima, miniranjem i paljenjem kuća, pljačkom imovine, psihičkim pritiscima od strane srpskih vojnih i policijskih jedinica i civilnih vlasti. Ovakvim postupanjima vršena su teška kršenja međunarodnog humanitarnog prava. Zapravo, na okupiranim područjima, srpske vojne i policijske jedinice i vlast stvarali su takve prilike i atmosferu kojoj nije bilo alternative, osim prisilnog odlaska nesrpskog stanovništva s ovih prostora. Potvrdu navedenog nalazimo $\mathrm{u}$

${ }^{24}$ ICTY, Predmet br. IT-99-06-T, PRED PRETRESNIM VIJEĆEM II, TUŽILAC PROTIV RADOSLAVA BRĐANINA, PRESUDA, 1. septembar 2004. paragraf 551. ${ }^{25}$ Isto, paragraf 554. 
razgovoru Birte Weiss s Radoslavom Brđaninom u zatvoru Nyborg $\mathrm{u}$ Danskoj. ${ }^{26}$ Brđanin je izjavio: "Ponašali su se kao divlji psi, pljačkali i bezobzirno ubijali. Te paravojne skupine su širile strah i užas oko sebe, tako da je narod želio otići." ${ }^{27}$ Ovdje se ne može govoriti o želji za odlaskom, nego se radi o nasilnim odlascima koji su bili prouzrokovani strahom za vlastiti život i život svojih najbližih. Nasilno protjerani bili su svjedoci ubijanja, silovanja, odvođenja u logore, pljačke i uništavanja imovine $\mathrm{i}$ sve je to samo ubrzalo nasilne progone. ${ }^{28}$ Kako se navodi u presudi MKSJ u predmetu Radoslav Brđanin: "Već i prije izbijanja oružanog sukoba u $\mathrm{BiH}$, bosanski Muslimani i bosanski Hrvati koji su živjeli u Bosanskoj krajini osjećali su se sve manje bezbjedni i počeli su konvojima napuštati tu regiju. Daljim razvojem događaja $u$ Bosanskoj krajini, vlasti bosanskih Srba počele su od proljeća 1992. na cijeloj teritoriji Krajine provoditi aktivnu i sistematsku represiju i protjerivanja bosanskih Muslimana i bosanskih Hrvata. Vlasti bosanskih Srba su organizovale konvoje autobusa i vozove koji su desetine hiljada muškaraca, žena i djece odvozili s teritorija na koje su bosanski Srbi polagali pravo na teritoriju pod kontrolom bosanskih Muslimana unutar BiH ili Hrvatske. (...).“29

Kako se i pod kojim uslovima provodilo prisilno premještanje na čitavom prostoru Bosanske krajine, najbolje se vidi u presudi MKSJ u predmetu Radoslav Brđanin: “(...) Protjerivanja i prisilna premještanja su se sistematski provodila u cijelom ARK-u, u kojem i iz kojeg su trajno raseljene desetine hiljada bosanskih Muslimana i bosanskih Hrvata. (...) Vlasti bosanskih Srba su onima koje nisu protjerali, a koji nisu uspjeli da pobjegnu, nametnule nepodnošljive životne uslove, $\mathrm{u}$ kojima je bilo nemoguće nastaviti živjeti i koji su ih primorali da traže dozvolu za odlazak. Bosanskim Muslimanima i bosanskim Hrvatima

26 Begić, M., 2015. Genocid u Prijedoru, Institut za istraživanje zločina protiv čovječnosti i međunarodnog prava Univerziteta u Sarajevu, Hrvatski-memorijalno dokumentacijski centar domovinskog rata, Sarajevo, Zagreb, str. 167.

${ }^{27}$ Weiss, B., 2010. Nasljednici rata, Vrijeme, Zenica, str. 79.

${ }^{28}$ Begić, 2017. str. 753.

${ }^{29}$ ICTY, Predmet br. IT-99-06-T, PRED PRETRESNIM VIJEĆEM II, TUŽILAC PROTIV RADOSLAVA BRĐANINA, PRESUDA, 1. septembar 2004. paragraf 116. 
bilo je ograničeno kretanje i živjeli su izloženi opasnosti; od njih se tražilo da potpišu izjavu o lojalnosti vlastima bosanskih Srba (...).“"30

Način progona onih osoba koje su ostale kod svojih kuća nalazimo u presudi MKSJ u predmetu Momčilo Krajišnik, gdje se navodi: "Uprkos ubistvima, hapšenjima i raširenoj diskriminaciji, dio Muslimana i Hrvata je odlučilo ostati u svojim domovima ili jednostavno nije imalo drugog izbora. U tim slučajevima, srpske vlasti i srpske snage su te grupe često fizički istjerivale. To se dogodilo u mnogim opštinama, uključujući Banju Luku, Bijeljinu, Bosansku Krupu, Bosanski Novi, Bosanski Petrovac, Bratunac, Brčko, Čajniče, Foču, Gacko, Hadžiće, Novi Grad, Novo Sarajevo, Pale, Prnjavor, Sanski Most, Trnovo, Vlasenicu i Zvornik." ${ }^{31}$ Kao primjer masovnog iseljavanja Bošnjaka i Hrvata je i Banja Luka. U redovnom borbenom izvještaju komande 1. krajiškog korpusa navodi se: "U gradu Banja Luka i ostalim većim mestima stalno je u porastu zahtev i organizirano iseljavanje hrvatskog i muslimanskog stanovništva. Smatramo da na ovome vlasti opština i regije trebaju daleko više raditi. (...) Sve veći problem predstavljaju sabirni centri, odnosno logori ratnih zarobljenika, pitanje je šta raditi dalje." 32

Stanovnici bošnjačke i hrvatske nacionalnosti s područja opština Bosanske krajine koji su morali pobjeći pred napadima srpskih vojnih i policijskih jedinica ili su nasilno protjerani, boravak su našli u opštinama Cazin, Bihać, Velika Kladuša, Gračanica, Travnik, Zenica, Posušje, na području Republike Hrvatske i drugim zemljama širom Evrope. $^{33}$

\footnotetext{
${ }^{30}$ Isto, paragraf 551.
}

${ }^{31}$ ICTY, Predmet br. IT-00-39-T, PRED PRETRESNIM VIJEĆEM I, TUŽILAC PROTIV MOMČILA KRAJIŠNIKA, PRESUDA, 27. septembar 2006. paragraf 730. 32 AIIZ, inv. br. 2421, Komanda 1. Krajiškog korpusa, Op. str. pov. br. 44-1/263, 28. juli 1992. REDOVNI BORBENI IZVJEŠTAJ GLAVNOM ŠTABU VOJSKE SrR BiH.

${ }^{33}$ (...) velik broj Muslimana iz Banje Luke, Bijeljine, Bileće, Bosanskog Novog, Bratunca, Brčkog, Čajniča, Doboja, Foče, Gacka, Nevesinja, s Pala, iz Prnjavora, Rogatice, Sanskog Mosta, Vlasenice i Zvornika raseljen u Hrvatsku, Makedoniju ili neko drugo mjesto izvan teritorije pod kontrolom bosanskih Srba. Vijeće nadalje, na osnovu predočenih dokaza, zaključuje da su iz nekoliko tih opština - konkretno iz Banje Luke, Doboja i Prnjavora - na isti način, premda u manjem broju, iseljavani i Hrvati. ICTY, Predmet br. IT-00-39-T, PRED PRETRESNIM VIJEĆEM I, 
$\mathrm{Na}$ prostoru Bosanske krajine, sedam tzv. srpskih opština (Bihać, Bosanski Petrovac, Krupa, Sanski Most, Prijedor, Bosanski Novi i Ključ) formirale su SUBREGIJU. Oni su na sastanku održanom 7. juna 1992. godine donijeli nekoliko zaključaka. U zaključku 6. navodi se: "Svih sedam opština naše subregije je saglasno da se sa teritorija naše opštine isele Muslimani i Hrvati do nivoa kad svaka od ovih opština može da održava efikasnu i ostvaruje srpsku vlast na svojoj teritoriji. (podvukao M. B.). U tom smislu tražimo od Kriznog štaba Autonomne regije Krajina da se omogući koridor za iseljavanje istih prema centralnoj Bosni u Alinu nezavisnu državu BiH, jer su oni za to i glasali. Ukoliko rukovodstvo Autonomne regije Krajina u Banja Luci ne bude rješavalo ovo pitanje, naših sedam opština će sve Muslimane i Hrvate sa teritorije naših opština pod vojnom pratnjom sprovesti u centar Banja Luke." 34 Ovaj zaključak je zapravo podudaran s odlukom Radoslava Brđanina o ostanku 2\% nesrpskog stanovništva na teritoriji ARK-a. Uz traženje nesmetanog progona prema “Alijinoj državi", uz prijetnje najavljuju progon Bošnjaka i Hrvata pod prijetnjom oružjem $u$ Banjaluku. Ovakva politika "progona u najavi" u konačnici je rezultirala masovnim progonom s prostora ovih sedam opština do kraja 1992. godine. U pojedinim opštinama ostao je neznatan i zanemariv broj Bošnjaka i Hrvata, a u nekim skoro nijedan Bošnjak (Bosanski Petrovac). ${ }^{35}$

U informaciji komande 1. krajiškog korpusa izvještava se da "deo muslimanskog i hrvatskog stanovništva se iseljava, a i Regija Bosanska Krajina donela je odluku da im se omogući iseljavanje pod uslovom da se dozvoli iseljavanje Srba iz centralne Bosne i mesta pretežno muslimanskim i hrvatskim stanovništvom. Za one koji se iseljavaju zabranjuje se svaki kasniji povratak (podvukao M. B.)."36

TUŽILAC PROTIV MOMČILA KRAJIŠNIKA, PRESUDA, 27. septembar 2006. paragraf 728.

34 AIIZ, inv. br. 2-5216, 7. juni 1992. ZAKLJUČCI SA SASTANKA SUBREGIJE (POLITIČKI PREDSTAVNICI SLJEDEĆIH OPŠTINA): BIHAĆ, BOS. PETROVAC, SRPSKA KRUPA, SANSKI MOST, PRIJEDOR, BOS. NOVI I KLJUČ, SANSKI MOST.

${ }^{35}$ Begić, 2017. str. 756.

36 AIIZ, inv. br. 5-1861, Komanda 1. KK, op. pov. br. 482-1, 1. juni 1992. INFORMACIJA O AKTUELNOJ POLITIČKO-BEZBEDONOSNOJ SITUACIJI. 
U presudi MKSJ u predmetu Momčilo Krajišnik, progon Bošnjaka i Hrvata s prostora opština Bosanske krajine spominje se u kontekstu ukupnih progona u Bosni i Hercegovini. U tom smislu, u presudi se navodi: "Vijeće zaključuje da je velik broj Muslimana u Bijeljini, Bosanskoj Krupi, Bosanskom Novom, Bosanskom Petrovcu, Bratuncu, Čajniču, Čelincu, Donjem Vakufu, Foči, Gacku, Hadžićima, Ilidži, Ilijašu, Ključu, Kotor-Varoši, Novom Gradu, Novom Sarajevu, na Palama, u Prijedoru, Rogatici, Sanskom Mostu, na Sokocu, u Trnovu, Višegradu i Zvorniku raseljen iz svojih domova u druga mjesta $u$ istoj opštini ili u druge opštine na teritoriji pod kontrolom bosanskih Srba. Vijeće nadalje, na osnovu predočenih dokaza, zaključuje da su iz nekoliko od tih opština - konkretno, iz Bosanske Krupe, Hadžića, Novog Grada, Prijedora i Sanskog Mosta na isti način, premda $\mathrm{u}$ manjem broju, iseljavani i Hrvati. “37

Napadajući nebranjena naselja i mjesta glavni je "cilj napada bio prisilno premještanje bosanskih Muslimana i bosanskih Hrvata kako bi se promijenio nacionalni sastav neke opštine ili manje teritorije unutar opštine. Taj napad je proveden u svim opštinama na koje se Optužnica odnosi i iziskivao je angažman vlasti bosanskih Srba na centralnom, regionalnom i opštinskim nivou. Vijeće stoga zaključuje da je taj napad bio i rasprostranjen i sistematski (...). Zatim, da je sam napad očito bio usmjeren protiv civilnog stanovništva muslimanske i hrvatske nacionalnosti. ${ }^{38}$

U presudi MKSJ u predmetu Radoslav Brđanin: "Pretresno vijeće se van razumne sumnje uvjerilo da je isključiva namjera vlasti bosanskih Srba pri prisilnom premještanju bosanskih Muslimana $i$ bosanskih Hrvata unutar ARK-a i van ARK-a bila da osiguraju trajan odlazak tih stanovnika (podvukao M. B.). Na to ukazuje činjenica da su njihovi domovi, radnje i vjerski objekti razoreni, a njihova imovina konfiskovana ili bez naknade predata u posjed Srpskoj Republici BiH. Nema sumnje da su vlasti bosanskih Srba smatrale da će etničko čišćenje biti uspješno samo ako se bosanski Muslimani $i$ bosanski

${ }^{37}$ ICTY, Predmet br. IT-00-39-T, PRED PRETRESNIM VIJEĆEM I, TUŽILAC PROTIV MOMČILA KRAJIŠNIKA, PRESUDA, 27. septembar 2006. paragraf 727. ${ }^{38}$ Isto, paragraf 710. 
Hrvati trajno uklone (podvukao M. B.)." 39 Iz navedene presude jasno se vidi da je MKSJ utvrdio prave namjere i ciljeve prisilnog premještanja i deportovanja Bošnjaka i Hrvata.

Kako se navodi u presudi MKSJ u predmetu Radoslav Brđanin: "Ponekad je pod prividom procesa preseljenja stanovništva vršeno 'etničko čišćenje'. U Banjoj Luci je Agencija za preseljenje ljudi i razmjenu dobara (dalje u tekstu: Agencija), osnovana 12. juna 1992. u skladu s odlukom Kriznog štaba ARK-a, pomagala u razmjeni stanova i preseljenju stanovništva. Agencija je bila poznata kao 'Perkina agencija' ili kao 'Brđaninova agencija'. Prema mišljenju Pretresnog vijeća, iako je Agencija bila osnovana radi razmjene stanova i preseljenja stanovništva, to nije bilo ništa drugo nego integralni dio plana etničkog čišćenja." 40

O razmjerama progona bošnjačkog stanovništva navedeno je u Odluci po prijedlogu za donošenje oslobađajuće presude MKSJ u predmetu Slobodan Milošević gdje se navodi da je na području više opština koje su bile okupirane ${ }^{41}$ živjelo "344.803 Muslimana. Od tog broja ih je 1997-1998. ostalo oko 7.933 (odnosno oko 1,4 odsto). ${ }^{642}$ Ovi podaci ukazuju na razmjere prisilnih progona i deportacija.

${ }^{39}$ ICTY, Predmet br. IT-99-06-T, PRED PRETRESNIM VIJEĆEM II, TUŽILAC PROTIV RADOSLAVA BRĐANINA, PRESUDA, 1. septembar 2004. paragraf 548. ${ }^{40}$ Isto, paragraf 552.

${ }^{41}$ Opštine: Banjaluka, Bihać, Bijeljina, Bileća, Bosanska Dubica, Bosanska Gradiška, Bosanska Krupa, Bosanski Novi, Bosanski Petrovac, Bosanski Šamac, Bratunac, Brčko, Čajniče, Čelinac, Doboj, Donji Vakuf, Foča, Gacko, Goražde, Kalinovik, Ključ, Kotor Varoš, Nevesinje, Prijedor, Prnjavor, Rogatica, Rudo, Sanski Most, Sarajevo - Centar, Sarajevo - Hadžići, Sarajevo - Ilidža, Sarajevo - Ilijaš, Sarajevo - Novi Grad, Sarajevo - Novo Sarajevo, Sarajevo - Pale, Sarajevo - Stari Grad, Sarajevo - Trnovo, Sarajevo - Vogošća, Sokolac, Srebrenica, Šekovići, Šipovo, Teslić, Trebinje, Višegrad, Vlasenica i Zvornik. ICTY, Predmet br. IT-02-54-T, TUŽILAC PROTIV SLOBODANA MILOŠEVIĆA, ODLUKA PO PRIJEDLOGU ZA DONOŠENJE OSLOBAĐAJUĆE PRESUDE, 16. juni 2004. paragraf 232, napomena 577.

${ }^{42}$ Isto, paragraf 232. 


\section{Nasilni progon i prisilne deportacije Bošnjaka i Hrvata - slučaj opština Ključ, Sanski Most, Prijedor, Banja Luka i druge opštine Bosanske krajine}

\section{a) Opština Ključ}

Nasilni progoni i prisilne deportacije Bošnjaka i Hrvata s područja opštine Ključ vršena su planski i sistematski kao dio kampanje srpskih civilnih vlasti, vojnih i policijskih snaga o trajnom napuštanju prostora za koje su oni smatrali da im pripadaju. Ključni razlozi da Bošnjaci i Hrvati prisilno napuste opštinu Ključ bili su svakodnevni napadi, ubijanje, nezakonita zatočenja u koncentracione logore, uništavanje džamija i katoličke crkve, pljačkanje, silovanje, zastrašivanje i drugi oblici pritisaka kako bi ubrzali nesrpsko stanovništvo da trajno napusti svoje domove. ${ }^{43}$

Ratno predsjedništvo srpske opštine Ključ na sjednici održanoj 30. jula. 1992. godine, donijelo je odluku o kriterijima za mogućnost iseljenja s područja opštine Ključ. U članu 1 ove odluke omogućava se napuštanje opštine Ključ po kriterijima propisanim ovom odlukom licima koja daju izjavu (Komisiji za prikupljanje podataka vezanim za iseljenje) o trajnom napuštanju teritorije opštine Ključ. Član 2 odluke govori da "trajno iseljenje s područja opštine Ključ dozvoljava se i licima koja svoju nepokretnu imovinu ostavljaju opštini Ključ. Ne dozvoljava se prodaja pokretne, nepokretne imovine i putničkih vozila. ${ }^{\text {"44 }} \mathrm{U}$ organizaciji srpske opštine Ključ, SJB Ključ i Crvenog krsta Ključ vršeno je nasilno deportovanje Bošnjaka i Hrvata iz Ključa. Deportacije su vršene konvojima pravcem Ključ - Skender-Vakuf - Travnik i Ključ - Bosanska Gradiška. Spiskove i odobrenja za deportacije radila je Stanica javne bezbjednosti (dalje: SJB) Ključ kao i pratnju konvoja. SJB Ključ je određivao koje osobe treba transportovati na područja pod kontrolom A R BiH, a koja u logore. Najveći broj Bošnjaka nasilno je

43 Begić, M., 2012. Genocid u Ključu, Institut za istraživanje zločina protiv čovječnosti i međunarodnog prava Univerziteta u Sarajevu, Sarajevo, str. 172.

44 AINOBiHPUB, SRPSKA REPUBLIKA BOSNA I HERCEGOVINA, SKUPŠTINA OPŠTINE KLJUČ, RATNO PREDSJEDNIŠTVO, Broj: 05-1_/92, ODLUKA O KRITERIJIMA ZA MOGUĆNOST ISELJENJA SA PODRU $\check{C} J A$ OPŠTINE KLJUČ. 
protjeran u ljeto 1992. godine, i to u periodu juni - septembar 1992. godine. $^{45}$

Prema svjedočenjima očevidaca, koji su vidjeli autobuse s nasilno protjeranim Bošnjacima i Hrvatima, 5. septembra 1992. godine iz Ključa je nasilno protjerano u 50 autobusa oko 5.000 ljudi. Protjerani su bili iz Velagića, Velečeva, Dubočana, Šehića, Krasulja i drugih mjesta ključke opštine. Protjerivanje je nastavljeno i 13. septembra 1992. godine, kada je oko 160 Bošnjaka protjerano iz Ključa. Tokom čitavog puta su maltretirani, otiman im je novac i druge vrijedne lične stvari. ${ }^{46}$

Koliko je u 1992. godini nasilno protjerano i deportovano Bošnjaka i Hrvata iz opštine Ključ vidi se iz slijedećeg: "Početkom maja 1993. godine milicija je izvršila popis stanovništva muslimanske vjeroispovjesti i našla sledeće stanje: - u MZ Sanica ima ih 89, - u MZ Previje 3,-u MZ Peći zaseok Kalabe 221, - u MZ Humići 275, - u MZ Ključ 992. Među ovih 1.510 građana ima ih 306 vojno sposobnih za rat, najveća im je koncentracija u samom gradu Ključu, a potom dođe u MZ Humići. “47

O broju Bošnjaka koji su prisilno napustili svoja ognjišta u periodu maj 1992 - 31. 1.1993. godine govori se u izvještaju ${ }^{48}$ pomoćnika komandanta 1. krajiškog korpusa za civilne poslove od 16. februara 1993. godine. U izvještaju se navodi: “ - iz MZ Peći od 2.815 koliko ih je bilo iselilo se 2.655 još ih je ostalo 160 u 32 domaćinstva. Ova domaćinstva su iz s. Krasulje, zaseok Kolibe (Kalabe prim. M.B.), 24 domaćinstva i u s. D. Krasulje 8 domaćinstava, - iz MZ Humići od 1.732 koliko ih je bilo iselilo se oko 1.250, a ostalo ih je 482. Ovi koji su ostali ne žele da se sele, a imaju veliku nadu da će se povratiti i oni koji su se iselili. Vjerovati je da će se još o tome raspravljati ko će se vraćati a ko neće, - MZ Sokolovo od 778 koliko ih je bilo iselili su se svi. Živili su u selima Crljeni i selu Prhovo, - MZ G. Ribnik od 24

\footnotetext{
${ }^{45}$ Begić, 2012. str. 172.

46 Isto, str. 180.

${ }^{47}$ AINOBiHPUB, VP 7286 Ključ, pov. br. 15/93, 19. maj 1993., INFORMACIJA O STANJU NA PODRUČJU KLJUČKE OPŠTINE PO CIVILNIM POSLOVIMA, str. 3. 48 AINOBiHPUB, VP 7286 Ključ, pov. br. 01-326-22/93, 16. februar 1993. IZVJEŠTAJ.
} 
koliko ih je bilo s. Velije u 5 kuća svi su se iselili, - MZ Ključ od 4.516 iz tri prigradska sela i to iz: s. Velečevo, Dubočani i Zgon iselili su se svi stanovnici njih 1.425, međutim, iz grada iselilo se oko 2.180 ostalo je oko 884 . Među ovim ostalim ima i onih koji se spremaju i spremni su da se isele. “ 49

Od svih mjesnih zajednica na području opštine Ključ u maju 1993. godine, samo u 5 mjesnih zajednica bilo je Bošnjaka. Od 17.696 Bošnjaka po popisu iz 1991. godine ${ }^{50}$ u maju 1993. godine ostalo je 1.510 Bošnjaka, dok je 16.186 osoba bošnjačke nacionalnosti protjerano, zatočeno ili ubijeno. Depešom od 5. januara 1994. godine, koju je SJB Ključ uputila CSB Banja Luka i MUP-u RS Bijeljina obavještava ih da je $\mathrm{u}$ Ključu $\mathrm{u}$ tom trenutku bilo 1.445 građana bošnjačke nacionalnosti i 124 Hrvata. $^{51}$ Ovo je rezultat provođenja politike nestanka Bošnjaka i Hrvata s područja opštine Ključ. Iz ovog slijedi da je na području opštine Ključ ostalo samo $8,6 \%$ prijeratne populacije.

Konačno, pojedinačnim progonima od januara 1994. do septembra 1995. godine, skoro da nije bilo nesrpskog stanovništva na području opštine Ključ. U septembru 1995. godine, nakon što su jedinice 5. korpusa A R BiH oslobodile Ključ, zatekle su 306 stanovnika nesrpske nacionalnosti ili $0,55 \%$ od onih koji su živjeli na području opštine Ključ po popisu iz 1991. godine. ${ }^{52}$

\section{b) Opština Sanski Most}

I prije otpočinjanja napada srpskih vojnih i policijskih snaga jedan broj građana opštine Sanski Most iselio se tražeći sigurnost za sebe i svoje porodice. U jednom od izvještaja SJB Sanski Most navedeno je: “prema operativnim saznanjima SJB Sanski Most sa područja opštine se

49 AINOBiHPUB, VP 7286 Ključ, pov.br. 01-326-22/93, 16. februar 1993. IZVJEŠTAJ, str.4.

${ }^{50}$ Nacionalni sastav stanovništva, Rezultati za Republiku po opštinama i naseljenim mjestima 1991. Statistički bilten br. 234, Državni zavod za statistiku RBiH, Sarajevo, 1993.

51 AINOBiHPUB, SJB KLJUČ, 5. januar 1994. DEPEŠA MUP-u RS BILJELJINA, CSB BANJA LUKA.

52 Begić, 2012. str. 180. 
odselilo oko 3.000 lica prije otpočinjanja oružanih sukoba, uglavnom žena, djece i starijih osoba (...). ${ }^{53}$

Proces prisilnog progona i deportacija na području opštine Sanski Most krenuo je po otpočinjanju borbenih djelovanja srpskih snaga na nebranjena bošnjačka i hrvatska mjesta i naselja. Prvo su vršeni prisilni progoni iz mjesta koja su srpske vojne i policijske snage napadale $u$ druga mjesta koja nisu bila meta trenutnih napada, a nakon toga progoni i deportacije van teritorije opštine Sanski Most. Naredbom Kriznog štaba Srpske opštine Sanski Most od 24. maja 1992. godine formiran je Štab civilne zaštite Sanski Most koji je imao zadatak evakuacije progona Bošnjaka i Hrvata. ${ }^{54} \mathrm{U}$ informatoru SDS-a navodi se: “(...) Poslije dejstva na području grada, Štab se uključio u evakuaciju stanovništva koje nije učestvovalo u pružanju oružanog otpora u druga područja grada i Sportsku dvoranu." 55

Prvi pokušaj prisilnog progona i deportacije veće grupe civila, žena i djece, bila je u pravcu Jajca. Prva grupa prisilno deportovanih na teritoriju pod kontrolom legalnih vlasti Republike Bosne i Hercegovine bila je početkom juna 1992. godine. Protjerane žene, djeca i stariji iz naselja Mahala, Muhići, Otoka, Hrustovo i drugih dijelova opštine koji su boravili u Pobriježju protjerani su prema Velikoj Kladuši. ${ }^{56}$ Prema podacima iz presude MKSJ u predmetu Radoslav Brđanin: "1.080 izbjeglica protjerano iz Podbriježja i u pratnji civilne policije odvezeno u pravcu Velike Kladuše." ${ }^{\text {, }}$ Prema podacima Crvenog krsta Velike Kladuše, broj prisilno raseljenih i deportovanih s područja opštine

\footnotetext{
${ }^{53}$ AIIZ, inv. br. 2-4674, Srpska Republika, Ministarstvo za unutrašnje poslove, Centar službi bezbjednosti, IZVJEŠTAJ O ZATEČENOM STANJU I PITANJIMA U VEZI SA ZAROBLJENICIMA, SABIRNIM CENTRIMA, ISELJAVANJU I ULOZI SJB U VEZI S OVIM AKTIVNOSTIMA, str. 8-11.

${ }^{54}$ Begić, 2017, str. 767.

55 AIIZ, inv. br. 5-2062, INFORMATOR SRPSKE DEMOKRATSKE STRANKE SANSKI MOST, Broj 1, Informativno propagandni centar Srpske demokratske stranke, Petrovdan (12. juli) 1992. godine.

${ }^{56}$ Begić, 2017. str. 767.

${ }^{57}$ ICTY, Predmet br. IT-99-06-T, PRED PRETRESNIM VIJEĆEM II, TUŽILAC PROTIV RADOSLAVA BRĐANINA, PRESUDA, 1. septembar 2004. paragraf 547, napomena 1394.
} 
Sanski Most, koji je privremeni boravak našao na području opštine Velika Kladuša, bio je $739 .^{58}$

Nakon napada srpskih vojnih jedinica na Muhiće, Mahalu i Otoku i naredbe za napuštanje svojih domova počeo je prvi progon Bošnjaka i Hrvata s ovih prostora. ${ }^{59}$ U proglasu emitiranom na Radio Sani navodi se: "Rejonski štab lijeve obale obavještava sve izbjeglice koje su smještene u sledećim ulicama i naseljima: naselje Narodni Front, Omladinska ulica, naselje Alagića Polje, Ulica Marije Bursać, Ulica Cvije Kukolja, Ulica prvomajska do nule, Rudarska do Otoke, naselje Mladena Stojanovića i Veljka Miljevića od robne kuće do Pobriježja da trebaju u 14 sati i 30 minuta izići pred osnovnu školu 'Narodni Front'. Sa sobom ponijeti svoje stvari. Svima njima je obezbijeđena sigurnost pri smještaju u Pobriježju i Starom Majdanu. Poslije 14 sati i 30 minuta izvršiće se pretres stanova pa zato upozoravamo izbjeglice i njihove domaćine da ne bi nikog skrivali u stanovima. Krizni štab." 60 Ovim pozivom počeo je progon iz navedenih naselja. ${ }^{61}$ Nakon progona, Krizni štab srpske opštine Sanski Most 30. maja 1992. godine, donio je slijedeće zaključke: "Problem izbjeglica iz reona Mahale kao i problem sa Muslimanima i Hrvatima koji nisu lojalni Ustavu i zakonima Srpske Republike BiH rješavati dugoročno (podvukao M. B.) a to znači omogućiti iseljenje svim onima koji nisu uzimali oružje u ruke, a žele promijeniti opštinu. Takođe uspostaviti vezu sa rukovodstvom Autonomne regije Krajina o realizaciji ideje o preseljenju stanovništva. (...) a) 3. Napraviti spisak ratno sposobnih izbjeglica iz Mahale pritvorenih u Sportskoj dvorani u Školskom centru zadužen Nemanja Tripković."62

U jednom izvještaju SJB Sanski Most navode se pravi razlozi za prisilni progon i iseljavanja Bošnjaka i Hrvata: “(...) a) Na području opštine

\footnotetext{
58 Muhamedagić, H., 2007. Privremeni boravak izbjeglica i raseljenih osoba na području opštine Velika Kladuša 1991-1995. Grafičar, Velika Kladuša, str. 462.

${ }^{59}$ Begić, 2017. str. 757.

${ }^{60}$ AIIZ, inv. br. 5-1963, TRANSKRIPT RAZGOVORA NA “RADIO SANSKI MOST”, str. 7.

${ }^{61}$ Begić, 2017, str. 758.

${ }^{62}$ AIIZ, inv. br. 5-1918, Krizni štab srpske opštine Sanski Most, broj: KŠ-27/92, 30. maj 1992. ZAKLJUČCI.
} 
Sanski Most u zadnjih dva mjeseca (...), a koje vode svoje privatne akcije koje se ogledaju u podmetanju eksplozija, paljenja kuća, ubistava, pljački i drugih vidova krivičnih djela prema muslimanskom i hrvatskom življu, a sve u cilju sticanja materijalne koristi i pritiska za njihovo iseljavanje (podvukao M. B.)." ${ }^{, 63}$ Krizni štab srpske opštine Sanski Most je svojim odlukama propisivao način "dobrovoljnog iseljavanja” Bošnjaka i Hrvata. Na sjednici Kriznog štaba održanoj 2. jula 1992. godine, Krizni štab opštine Sanski Most je donio Odluku o kriterijima za mogućnost iselenja sa područja opštine ${ }^{64}$ : "u članu 1. Odluke: Dozvoljava se dobrovoljno napuštanje teritorije opštine Sanski Most porodicama i licima koja daju izjavu kod nadležnog opštinskog organa uprave (Opštinski sekretarijat za opštu upravu, prostorno uređenje i stambeno komunalne poslove) da trajno napuštaju teritoriju opštine i da svoju nepokretnu imovinu ostavljaju na raspolaganje Opštini Sanski Most. Na osnovu date izjave ili ugovora Opštinski sekretarijat za narodnu odbranu će ukoliko ne postoje zakonske smetnje, izdati takvim licima potrebnu saglasnost za napuštanje teritorije opštine Sanski Most. Član 5. Dokument o trajnom iseljenju sa područja opštine donosi Stanica javne bezbjednosti Sanski Most na bazi prethodnih dokumenata i provjera." 65

Ovom odlukom propisani su uslovi pod kojima građani opštine Sanski Most, bošnjačke i hrvatske nacionalnosti mogu napustiti svoje domove. Prvi, uslov za napuštanje opštine Sanski Most je da trajno napuštaju svoje domove i drugi - da svoju nepokretnu imovinu (kuće, stanove) ostavljaju na raspolaganju srpskoj opštini Sanski Most. Sve su to morali uraditi pismenim putem da bi od SJB srpske opštine Sanski Most dobili konačnu dozvolu. ${ }^{66} \mathrm{O}$ istom je navedeno u presudi MKSJ u predmetu Momčilo Krajišnik gdje se navodi: "Krizni štab je, nadalje, 2. jula 1992. odlučio da se dozvoli odlazak osobama koje su opštinskim vlastima

63 AIIZ, inv. br. 2417, Srpska Republika Bosna i Hercegovina, Ministarstvo za unutrašnje poslove, Centar službi bezbjednosti Banja Luka, Stanica javne bezbjednosti, Sanski Most, broj: 11-14-1275/92, 5. august 1992. IZVJEŠTAJ.

${ }^{64}$ Begić, 2017. str. 759.

${ }^{65}$ AIIZ, inv. br. 5-1909, Krizni štab opštine Sanski Most, 2. juli 1992. ODLUKAO KRITERIJIMA ZA MOGUĆNOST ISELENJA SA PODRUČJA OPŠTINE.

${ }^{66}$ Begić, 2017. str. 762. 
prethodno dale izjavu da zauvijek odlaze iz opštine i koje su razmijenile svoju nepokretnu imovinu ili je prepustile opštini." 67

Kakvu je ulogu u progonu stanovništva bošnjačke i hrvatske nacionalnosti s područja opštine Sanski Most imala Srpska demokratska stranka (dalje:SDS) opštine Sanski Most vidi se kada: "Opštinski odbor Srpske demokratske stranke Sanski Most na sastanku održanom 24. 6. 1992. godine, shodno Statutu Srpke demokratske stranke donosi zaključke, 2. Sukob naroda se najefikasnije i najmirnije rješava preseljenjem naroda sa jednog na drugo područje. U tom smislu i raditi da se jedan dio Muslimana i Hrvata preseli iz Sanskog Mosta u Centralnu Bosnu (podvukao M. B.), a Srbi izbjegli sa teritorija gdje su manjina dosele u Sanski Most." ${ }^{68}$ Iz navedenog zaključka jasno je opredjeljenje SDS-a opštine Sanski Most da izvrši progon nesrpskog stanovništva iz opštine Sanski Most. Ono što je posebno uočljivo je njihova konstatacija: "sukob naroda se najefikasnije $i$ najmirnije rješava preseljenjem naroda sa jednog na drugo područje”, što je potpuni paradoks imajući u vidu činjenicu da je najveći broj naselja $s$ bošnjačkim i hrvatskim stanovništvom razoren, uništen, velik broj ljudi ubijen, zatočen u brojnim logorima $\mathrm{i}$ jedan broj nasilno protjeran $\mathrm{s}$ područja opštine Sanski Most. ${ }^{69}$

Dana 1. juna 1992. godine, putem Radija Sana, Krizni štab Srpske opštine Sanski Most izdao je proglas sadržine: "Svim građanima muslimanske i hrvatske nacionalnosti, koji iz bezbjedonosnih i drugih razloga žele da napuste opštinu Sanski Most, biće omogućen odlazak. Zainteresovani se radi evidencije $i$ uputstava mogu prijaviti u zgradu Opštine, kancelarija broj tri počevši od 1. 6. '92. godine u vremenu od osam do 16 časova. Krizni štab."70

${ }^{67}$ ICTY, Predmet br. IT-00-39-T, PRED PRETRESNIM VIJEĆEM I, TUŽILAC PROTIV MOMČILA KRAJIŠNIKA, PRESUDA, 27. septembar 2006. paragraf 531 ${ }^{68}$ AIIZ, inv. br. 5-2063, Srpska demokratska stranka BiH, Opštinski odbor Sanski Most, broj: 42/92, 6. juli 1992. ZAKLJUČCI.

${ }^{69}$ Begić, 2017. str. 762.

${ }^{70}$ AIIZ, inv. br. 5-1963, TRANSKRIPT RAZGOVORA NA "RADIO SANSKI MOST", str. 6; AIIZ, inv. br. 5-1921, Krizni štab srpske opštine Sanski Most, broj: KŠ-39/92, 23. juni 1992. ZAKLJUČCI; ICTY, Predmet br. IT-00-39-T, PRED PRETRESNIM 
Krizni štab srpske opštine Sanski Most na sastanku održanom 22. juna 1992. godine donio naredbu broj: KŠ-39-2/92 od 23. juna 1992. godine, kojom Boško Banjac naređuje da se formira komisija za migraciju stanovništva od 5 članova. ${ }^{71}$

Kakve su bile prave namjere i šta je bio cilj vlasti srpske opštine Sanski Most $\mathrm{u}$ odnosu na prisilna iseljavanja navedeno je $\mathrm{u}$ jednom zapisniku sa sjednice Izvršnog odbora srpske opštine Sanski Most: "Kamen spoticanja nove vlasti bio je što sa drugim narodima (muslimanima i hrvatima). Najhumanije je dozvoliti da se isele mirnim putem. Postignuti su određeni rezultati. Radi se da preko UNPROFORA preselimo ljude koji su zainteresovani za odlazak sa područja naše opštine. Moramo istrajati na ovim poslovima, jer to od nas traže borci, narod S. Mosta, jer ovo mora biti Srpski grad. (podvukao, M.B.)“72 Ovakav stav "da Sanski Most mora biti srpski grad" rezultirao je masovnim ubijanjima, zatvaranjima u logore i masovnim progonom Bošnjaka i Hrvata.

Da su uslovi ostanka u Sanskom Mostu bili nemogući za Bošnjake i Hrvate navodi se i u jednom od izvještaja SJB srpske opštine Sanski Most. U izvještaju se navodi: “(...) Ukupnu bezbjedonosnu situaciju u ovom mometu usložnjavaju samovoljne terorističke akcije pripadnika srpskog naroda prema muslimanskom i hrvatskom narodu koje imaju za cilj da se na njih izvrši pritisak i natjeraju na iseljavanje (podvukao M. B.). Ja sam na prošloj sjednici SO-e tražio da se odbornici odnosno SO-e odredi prema pitanjima muslimana i hrvata ali je prošlo nezapaženo. Naša je procjena da postojeći ekonomski, fizički, kulturni pritisak prema pripadnicima tih naroda odnosno etničkih grupa može u datom momentu biti kontraproduktivan i izazvati njihov bunt i pobunu protiv postojećeg sistema (srpske) vlasti. (...) grupe Srba pod firmom pritisaka na muslimane kaljaju obraz, ubijaju nevine ljude, pljačkaju zlato, pare i imovinu, pale kuće $i$ štale, ubijaju stoku itd (podvukao,

VIJEĆEM I, TUŽILAC PROTIV MOMČILA KRAJIŠNIKA, PRESUDA, 27. septembar 2006. paragraf 531.

${ }^{71}$ AIIZ, inv. br. 5-1906, Krizni štab srpske opštine Sanski Most, broj: KŠ-39-2/92, 23. juna 1992. NAREDBA.

72 AIIZ, inv.br. 5-2064, 27. juli 1992. ZAPISNIK SA 9. SJEDNICE IZVRŠNOG ODBORA SKUPŠTINE OPŠTINE SANSKI MOST, str. 5. 
M.B.). ${ }^{73}$ Iz navoda koji su prezentirani u navedenom izvještaju, jasno i nedvojbeno izneseni su ciljevi, pravi razlozi i načini na koji su Bošnjaci i Hrvati bili prisiljeni da napuste područje opštine Sanski Most. Ovakva postupanja prema građanima nesrpske nacionalnosti nisu mogli biti pojedinačni incidenti. Oni su dio širokog i sistematičnog plana u cilju trajnog uklanjanja ovih ljudi s prostora opštine Sanski Most. ${ }^{74}$

Nakon početnih napada u maju i junu 1992. godine, nastavak napada slijedio je i u narednim mjesecima (juli, august, septembar, oktobar, novembar 1992. godine) kako bi preostalo stanovništvo bilo prisiljeno napustiti svoja ognjišta. Tako se u informaciji o bezbjednosnoj situaciji na teritoriji opštine Sanski Most, SJB Sanski Most broj: 11-14 od 30. novembar 1992. godine, navodi: „,...) U poslednja dva mjeseca izvršeni su klasični oružani napadi na muslimanska sela Trnovu, Šehovce, Skucani Vakuf i Stari Majdan. U napadu su u svim slučajevima učestvovale veće grupe ljudi - rezervista od 6-30, a korišteno je pored streljačkog i teže naoružanje MB-60 mm, RB, zolje, bombe i eksploziv. ${ }^{75}$ Osnovni cilj ovih oružanih akcija je taj da se iz ovih naselja istjera muslimansko stanovništvo i natjera na iseljavanje jer je isto u tim naseljima ostalo brojno $i$ kompaktno. Jednostavno naši ljudi smatraju da su pojedine sredine radile u svoju korist $i$ iz tih naselja ili svoje blizine iselili neprijatelja, primjer: grad, Pobriježje, Dževar, B. Japra, Čirkići, Kamengrad, Čaplje, Kljevci, Kruhari itd. Da politika iseljavanja nije uradena kako treba i ravnomjerno zastupljena pa sami u tom smislu poduzimaju mjere (podvukao M. B.). - Jedan od motiva za istjerivanje i iseljavanje ljudi iz naselja je svakako i stvaranje uslova za pljačku napuštene imovine. Opšta je pojava da nakon što se muslimani $i$ hrvati isele redovnim putem ili bivaju istjerani oružanom akcijom nastupaju grupe naoružanih ljudi u 90\% slučajeva u uniformama $i$ 'kupe' tako ostavljene stvari i imovinu. Svi znamo da je to opšta pojava u cijeloj Republici Srpskoj, da to ne rade samo kradljivci

\footnotetext{
${ }^{73}$ AIIZ, inv. br. 5-1971, Republika Srpska, Ministarstvo za unutrašnje poslove, Centar službi bezbjednosti Banja Luka, Stanica javne bezbjednosti Sanski Most, broj:11-14, 6. oktobar 1992. IZVJEŠTAJU O BEZBJEDNOSNOJ SITUACIJI NA TERITORIJI OPŠTINE SANSKI MOST.

${ }^{74}$ Begić, 2017. str. 765.

75 Isto, str. 765.
} 
i lopovi nego i obični do juče pošteni ljudi. (podvukao M. B.)" ${ }^{976} \mathrm{Iz}$ izvještaja se jasno vidi da je cilj "iseliti neprijatelja iz svoje blizine" odnosno protjerati Bošnjake i Hrvate s ovih prostora. U drugom dijelu navedenog izvještaja koji govori o pljačkanju imovine govori se o razmjerima i počiniocima gdje je naglašeno da su pljačkaši ne samo kradljivci i “lopovi, nego i obični ljudi” iz čega se može zaključiti da je ovo bila masovna pojava. ${ }^{77}$

Prije trajnog progona s područja opštine Sanski Most, Bošnjaci i Hrvati su se morali pismenim putem odreći svoje imovine i istu ostaviti srpskoj opštini Sanski Most. Uz to su morali platiti sve komunalne troškove (struja, voda i drugo) i konačno platiti troškove prevoza. ${ }^{78}$

U skladu s Odlukom o kriterijima za mogućnost iselenja sa područja opštine Sanski Most, Bošnjaci i Hrvati su morali vršiti odjave prebivališta da bi dobili odobrenje za trajno napuštanje opštine Sanski Most. ${ }^{79}$ Tako se u izvještaj o zatečenom stanju i pitanjima u vezi sa zarobljenicima, sabirnim centrima, iseljavanju i ulozi SJB u vezi s ovim aktivnostima navodi: "Do dana 16. 08. 1992. godine Stanici javne bezbjednosti Sanski Most sa zahtjevom za odjavu prebivališta obratilo se oko 12.000 lica uglavnom muslimanske, a dijelom i hrvatske nacionalnosti. Ova lica su u prethodnom postupku pred nadležnom službom u SO-e Sanski Most dala izjavu da žele napustiti područje opštine trajno u cilju iselenja, a izjasnila su se u pogledu svoje nepokretne i pokretne imovine tako što su nepokretnu imovinu prodali ili poklonili, a pokretnu stavili na popis radi transporta. (... ${ }^{\star 680} \mathrm{O}$ broju Bošnjaka i Hrvata koji su bili primorani na odjavu prebivališta i napuštanje opštine Sanski Most navodi se u izvještaj o radu Stanice

\footnotetext{
${ }^{76}$ AIIZ, inv. br. 5-1981, Republika Srpska, Ministarstvo za unutrašnje poslove, Centar službi bezbjednosti Banja Luka, Stanica javne bezbjednosti Sanski Most, broj: 11-14, 30. novembar 1992. INFORMACIJA O BEZBJEDNOSNOJ SITUACIJI NA PODRUČJU OPŠTINE SANSKI MOST.

${ }^{77}$ Begić, 2017, str. 766.

78 Isto, str. 768.

${ }^{79}$ Isto, str. 769.

${ }^{80}$ AIIZ, inv. br. 2-4674, Srpska Republika, Ministarstvo za unutrašnje poslove, Centar službi bezbjednosti, IZVJEŠTAJ O ZATEČENOM STANJU I PITANJIMA U VEZI SA ZAROBLJENICIMA, SABIRNIM CENTRIMA, ISELJAVANJU I ULOZI SJB U VEZI S OVIM AKTIVNOSTIMA, str. 8-11.
} 
javne bezbjednosti za 1992. godinu, broj: 385/93, od januara 1993. godine: “(...) Ovde treba napomenuti da je u drugoj polovini godine na lični zahtjev u ovom odeljenju odjavljeno prebivalište oko 15.000 građana muslimanske i hrvatske nacionalnosti te izdato oko 10.000 potvrda o neposjedovanju oružja i 10.000 uvjerenja o nekažnjavanju. Ova dokumenta su tražili građani radi dobijanja papira i dozvola za iseljenje shodno raznim odlukama i propisima SO-e i drugih vlasti i organa Republike Srpske."

Da se radilo o masovnom i sistematičnom progonu koji je dosegao velike razmjere može se zaključiti iz podataka da je samo u dva mjeseca 12.000 Bošnjaka podnijelo zahtjeve i napustilo opštinu Sanski Most. ${ }^{82}$ U izvještaj o radu SJB za period 01.05. - 10.09.1992. godine, navodi se: "U okviru ove službe tokom mjeseca jula i avgusta izvršeno je 12.000 odjava stalnog mjesta boravka. Radnici su radili skoro danonoćno zbog veoma velikog broja zahtjeva pripadnika muslimanske nacionalnosti, (...)." ${ }^{\prime 83}$

Ovakvo masovno odjavljivanje i "napuštanje" opštine Sanski Most od strane Bošnjaka i Hrvata bilo je zbog nemogućih uslova života. Kakvi su bili uslovi života najbolje se vidi iz izvještaja broj: 11-14-1275/92 od 5. augusta 1992. godine gdje se navodi: “(...) a) Na području opštine Sanski Most u zadnjih dva mjeseca (...), a koje vode svoje privatne akcije koje se ogledaju u podmetanju eksplozija, paljenja kuća, ubistava, pljački i drugih vidova krivičnih djela prema muslimanskom i hrvatskom življu, a sve u cilju sticanja materijalne koristi i pritiska za njihovo iseljavanje. ${ }^{84}$

\footnotetext{
${ }^{81}$ AIIZ, inv. br. 5-1983, Republika Srpska, Ministarstvo za unutrašnje poslove, Centar službi bezbjednosti Banja Luka, Stanica javne bezbjednosti Sanski Most, broj: 385/93, januar 1993. IZVJEŠTAJ O RADU STANICE JAVNE BEZBJEDNOSTI ZA 1992. GODINU.

${ }^{82}$ Begić, 2017. str. 769.

${ }^{83}$ AIIZ, inv. br. 5-1984, Republika Srpska, Ministarstvo za unutrašnje poslove, Centar službi bezbjednosti Banja Luka, Stanica javne bezbjednosti Sanski Most, broj: 11-14, 10. septembar 1992. IZVJEŠTAJ O RADU SJB ZA PERIOD 01.05.-10.09.1992. GODINE.

${ }^{84}$ AIIZ, inv. br. 2417, Srpska Republika Bosna i Hercegovina, Ministarstvo za unutrašnje poslove, Centar služni bezbjednosti Banja Luka, Stanica javne
} 
Masovna iseljavanja planirana su od najviših organa vlasti srpske opštine Sanski Most. Tako u je u zapisniku sa 11. sjednice Izvršnog odbora SO-e Sanski Most, broj: 01-12-31/4 od 14. augusta 1992. godine, navedeno: “(...) 3. Prihvata se informacija Banjac Boška predsjednika Komisije za preseljavanje o toku postupka dobrovoljnog iseljavanja stanovništva sa područja opštine Sanski Most. - Omogućava se dobrovoljno iseljavanje svim licima koji su za to izrazili želju i koji imaju potrebnu dokumentaciju odnosno koji posjeduju teleks sa kojima im se garantuje smještaj. Sa iseljavanjem bi se trebalo otpočeti u utorak 18.08.1992. godine, prva tura, od oko 3.000 ljudi, s tim da će se organizovati prevoz autobusima 'Sanatransa'. Na ime troškova prevoza svako domaćinstvo koje se iseljava dužno je na račun sredstava solidarnost 'Sana' Sanski Most uplatiti iznos od 1.000 dinara." 85

U periodu juni - septembar 1992. godine u nekoliko konvoja, koji su organizovale srpske vlasti opštine Sanski Most, nekoliko hiljada Bošnjaka i Hrvata je deportovano preko planine Vlašić za Travnik. ${ }^{86} \mathrm{U}$ presudi MKSJ u predmetu Radoslav Brđanin navodi se: "Vlasti su organizovale konvoj u kojem je bilo otprilike 2.000 Muslimana muškaraca, žena, djece i staraca - koji su početkom avgusta 1992. otišli za Travnik. U pratnji konvoja kojim je 2. i 3. septembra 1992. godine otprilike 2.500 bosanskih Muslimana - muškaraca, žena, djece i staraca - otišlo u Travnik bila je i civilna i vojna policija bosanskih Srba."87

U planiranju prisilnog premještanja i deportacija Krizni štab srpske opštine Sanski Most planirao je da Bošnjake i Hrvate deportuje željezničkim putem - vozovima. U tom smislu tražio je da se "ispitaju

bezbjednosti, Sanski Most, broj: 11-14-1275/92, 5. august 1992. IZVJEŠTAJ; Objavljeno u M. Begić, Genocid u Sanskom Mostu, ..., str. 770.

${ }^{85}$ AIIZ, inv.br. 5-1907, Izvršni odbor srpske opštine Sanski Most, broj: 01-12-31/4, 14. august 1992. ZAPISNIK SA 11. SJEDNICE IZVRŠNOG ODBORA SO-e SANSKI MOST.

${ }^{86}$ Begić, 2017. str. 770.

${ }^{87}$ ICTY, Predmet br. IT-99-06-T, PRED PRETRESNIM VIJEĆEM II, TUŽILAC PROTIV RADOSLAVA BRĐANINA, PRESUDA, 1. septembar 2004. paragraf 560. 
mogućnosti prolaza konvoja ljudi koji se žele iseliti putem željeznice u područje centralne Bosne." 88

Koliko je Bošnjaka i Hrvata prisilno iseljeno i deportovano van područja opštine Sanski Most vidljivo je iz nekoliko izvještaja koji govore o broju iseljenih: “(...) Sa ovog područja iselilo je oko 20.000 Muslimana, a i preostali 10-tak hiljada to žele. Uglavnom, većina Muslimana seli zbog neizvjesnosti i nesigurnosti na ovom području. Takva neizvjesnost dolazi zbog samovolje pojedinaca i grupa koje nad građanima muslimanske nacionalnosti vrše torture i prisilu. Ima veći broj pojedinaca koji su za sebe prisvojili automobile, ugostiteljske radnje, što je donedavno bilo vlasništvo Muslimana i Hrvata. Svi pokušaji da se ovakvoj anarhiji, nasilju i bezvlašću stane u kraj za sada su ostali bez rezultata, (...)." ${ }^{, 89}$ Radi utvrđivanja broja građana na području pojedinih opština ARK-a, CSB Banja Luka je donio rješenje broj: 11-141/2, 14. augusta 1992. godine kojim se nalaže utvrđivanje broja odseljenih osoba. Prema podacima Izvršnog odbora srpske opštine Sanski Most krajem jula "na području opštine S. Most trenutno je ostalo oko 10.000 Muslimana i Hrvata za koje je da bi se izbjegla opasnost po srpski narod potrebno organizovati dobrovoljno iseljavanje." 90

Da je prisilni progon i deportacija bila dio sistematičnih i planiranih aktivnosti može se zaključiti iz dokumenta CSB Banja Luka iz maja 1993. godine pod nazivom pregled odseljenih i doseljenih građana koji pokriva sektor. ${ }^{91} \mathrm{U}$ tački IV navedeno je da je odseljeno: "Muslimana 24.000, Hrvata 3.000, Srba nema podataka; doseljeno: Srba 5.000."92 O istom je navedeno u presudi MKSJ u predmetu Momčilo Krajišnik: "U jednom izvještaju MUP-a iz maja 1993. piše da je iz te opštine otišlo

${ }^{88}$ AIIZ, inv. br. 5-1921, Krizni štab srpske opštine Sanski Most, broj: KŠ-39/92, 23. juni 1992. ZAKLJUČCI.

89 AIIZ, inv. br. 5-1964, Centar službi bezbjednosti-sektor SNB Banja Luka, Op. radnici: Radulović, Šajinović, Stjepanović, broj: 61/92, 19. oktobar 1992. SLUŽBENA ZABILJEŠKA.

${ }^{90}$ AIIZ, inv. br. 5-2052, Srpska opština Sanski Most, Izvršni odbor, broj: 01-012-28, 30. juli 1992. ZAKLJUČAK.

${ }^{91}$ Begić, 2017, str. 772.

${ }^{2}$ AIIZ, inv. br. 2-5202, PREGLED ODSELJENIH I DOSELJENIH GRAĐANA KOJI POKRIVA SEKTOR, str. 6. 
24.000 Muslimana i 3.000 Hrvata, te da se u nju uselilo 5.000 Srba."93 Broj od 24.000 protjeranih i deportovanih Bošnjaka najbolje govori o namjerama njihovog trajnog uklanjanja sa područja opštine Sanski Most. $^{94}$

Srpske vlasti su u periodu od 15 do 21. juna 1993. godine na području opštine Sanski Most izvršile popis preostalog stanovništva što potvrđuje Informacija opštinske komisije za popis. ${ }^{95}$ Prema rezultatima popisa na području opštine Sanski Most “(...) prema vjeroispovjesti i broju domaćinstava: 1993. godina, ukupno stanovnika 33.936, u 9.643 domaćinstva, pravoslavnih 27.792, Muslimana 4.390, katolika 1.247, ostalih 507, broj lica državljanstva Srpskog 32.529. ${ }^{96}$ Informaciju o provedenom popisu 1993. godine usvojila je Skupština opštine Sanski Most na sjednici održanoj 4. oktobra 1993. godine.“97 O istom, nalazimo u izvještaju, SJB Sanski Most u odgovoru na depešu br. 016/94 od 4. 1.1993. godine, poslanu MUP-u RS u Bijeljini gdje se navode podaci o broju građana opštine Sanski Most po popisu koji je urađen 1993. godine. Prema tom popisu na području opštine Sanski Most: “živjelo je 33.936 stanovnika, a) Srba 27.792, b) muslimana 4.390, v) hrvata $1.267, \mathrm{~g}$ ) ostalih 507. (...)"98

Ako uporedimo ove podatke s podacima po popisu stanovništva iz 1991. godine, gdje je opština Sanski Most imala ukupno 60.307 stanovnika od toga: Muslimani - Bošnjaci 28.136 ili (46,65\%), Srbi 25.363 ili (42,05\%), Hrvati 4.322 ili (7,16\%), Jugoslaveni 1.247 odnosno (2,06\%), ostali, neopredijeljeni i nepoznato $1.239(2,08 \%)$ jasno se vidi rezultat masovnih progona i deportacija. Iz ovih rezultata

${ }^{93}$ ICTY, Predmet br. IT-00-39-T, PRED PRETRESNIM VIJEĆEM I, TUŽILAC PROTIV MOMČILA KRAJIŠNIKA, PRESUDA, 27. septembar 2006. paragraf 532. ${ }^{94}$ Begić, 2017. str. 767.

${ }^{95}$ AIIZ, inv. br. 5-1969, Republika Srpska, Skupština opštine Sanski Most, Opštinska komisija za popis stanovništva i domaćinstava u 1993. godini za područje opštine Sanski Most, juli 1993. INFORMACIJA O IZVRŠENOM POPISU STANOVNIŠTVA I DOMAĆINSTAVA U 1993. GODINI NA PODRUČJU OPŠTINE SANSKI MOST.

${ }^{96}$ Isto.

${ }^{97}$ AIIZ, inv. br. 5-1970, Skupština opštine Sanski Most, broj: 01-012-29/9, 4. oktobra 1993. ZAKLJUČAK.

${ }^{98}$ AIIZ, inv. br. 5-1968, Stanica javne bezbjednosti Sanski Most, Depeša broj:11-1917/94, 5. januar 1993. DOSTAVA PODATAKA MUP-u RS BIJELJINA. 
vidljivo je da je s područja opštine Sanski Most nasilno protjerano i deportovano 23.746 Bošnjaka - Muslimana, Hrvata - katolika 3.075, Jugoslovena i ostalih protjerano je 1.979, dok se broj Srba pravoslavnih povećao za 2.429 građana. ${ }^{99}$

Prema podacima iz 1994. godine broj Bošnjaka i Hrvata koji su živjeli na području opštine Sanski Most dodatno je smanjen. Tako se u dokumentu SJB Sanski Most, Procjena bezbjednosne situaciji na staničnom području službena tajna str. pov. br: 11-19-23/94 od aprila 1994. godine, navodi: "U opštini živi oko 40.000 stanovnika od čega većinu čine građani srpske nacionalnosti oko 36.000 ili $90 \%$, Muslimana je nastanjeno oko 3.500 ili 9\% i Hrvata oko 400 što iznosi $1 \%$ stanovništva. Na području opštine nastanjeno je oko 4.000 izbjeglih lica uglavnom srpske nacionalnosti i to sa područja Hrvatske i centralne Bosne kao posledica ratnih sukoba na tim područjima. Priliv izbjeglica na područje opštine datira od 1991. godine a doseljavanje još uvijek traje." $" 100$

Prema presudi MKSJ u predmetu Stanišić, Simatović navodi se: “(...) nacionalni sastav stanovništva u opštini Sanski Most drastično se promenio u periodu od 1991. do 1997. godine: procenat nesrpskog stanovništva u onom delu opštine koji je pripadao Republici bosanskih Srba opao je za 86,4 posto." 101

Konačno, u septembru i oktobru 1995. godine, srpske vojne i policijske jedinice izvršile su nasilni progon najvećeg broja preostalog bošnjačkog i hrvatskog stanovništva opštine Sanski Most. Prije progona, u kuće i stanove u kojima su živjeli Bošnjaci i Hrvati, srpska policija i vojska uz znanje tadašnje vlasti, nasilno je useljavala srpske izbjeglice iz opština: Bihać, Bosanski Petrovac, Ključ te iz gradova u Republici Hrvatskoj.

\footnotetext{
${ }^{99}$ Begić, 2017. str. 775.

100 AIIZ, inv. br. 5-1982, Republika Srpska, Ministarstvo za unutrašnje poslove, Centar javne bezbjednosti Prijedor, Stanica javne bezbjednosti Sanski Most, Službena tajna str. pov. br: 11-19-23/94, april 1994. PROCJENA BEZBJEDNOSNE SITUACIJI NA STANIČNOM PODRUČJU

${ }^{101}$ ICTY, Predmet br. IT-03-69-T, PRED PRETRESNIM VIJEĆEM I, TUŽILAC PROTIV JOVICE STANIŠIĆA, FRANKA SIMATOVIĆA, JAVNO SA POVJERLJIVIM DODATKOM C, PRESUDA, 30. maj 2013. paragraf 809.
} 
Istjerivali su Bošnjake i Hrvate na ulicu i zabranjivali im da iz kuća i stanova uzmu bilo šta od imovine.

Nakon oslobađanja opštine Sanski Most (10. oktobar 1995. godine) od strane pripadnika A $\mathrm{R} \mathrm{BiH}$ zatečeno je 509 stanovnika nesrpske nacionalnosti na čitavom prostoru opštine Sanski Most ili 0,16 \% od popisa iz 1991. godine. ${ }^{102}$

\section{c) Opština Prijedor}

Na identičan način kao i u drugim dijelovima Bosne i Hercegovine i u Prijedoru su Bošnjaci i Hrvati bili izloženi nasilnom progonu i prisilnim deportacijama. Nasilni progoni Bošnjaka i Hrvata bili su dio smišljene i planirane kampanje nametanja takvih uvjeta života da su mnogi pristajali na sve uvjete srpskih vlasti općine Prijedor samo da bi napustali ovaj prostor. Na ovaj način, zapravo, su provođeni strateški ciljevi tzv. RS. Kako se navodi u presudi MKSJ u predmetu Radoslav Brđanin: “(...) postojala smislena, dosljedna strategija etničkog čišćenja koju je sprovodila policija bosanskih Srba i druge vlasti bosanskih Srba protiv bosanskih Muslimana i bosanskih Hrvata. Ova politika prisilnog premještanja bosanskih Muslimana i bosanskih Hrvata sa tog područja provodila se raznim sredstvima po cijelom ARK-u." 103 Progon stanovništva se odvijao na brutalan, prisilni način i uz uvjet da svako ko napušta općinu Prijedor, svoju nepokretnu imovinu pokloni i prepiše novoformiranim paradržavnim srpskim vlastima. ${ }^{104}$ Napuštanje imanja se odvijalo uz strogu kontrolu srpskih vlasti. Od imovine, prognani Bošnjaci i Hrvati su mogli ponijeti samo lične stvari i dio odjeće u zavežljaju. Pri ulasku na šlepere, autobuse i druga prevozna sredstva, tokom transporta i na kraju puta nadomak Vlašića i Travnika ili drugih mjesta progona, po uhodanom planu, bili su opljačkani od strane srpske vojske i policije. U Travnik su prognani dolazili nakon pješačenja oko petnaest kilometara, goli i bosi. Cilj prisilnog raseljavanja bilo je etničko čišćenje a jedini izbor za spas bilo je napuštanje Prijedora od

102 Begić, 2017. str. 786.

${ }^{103}$ ICTY, Predmet br. IT-99-06-T, PRED PRETRESNIM VIJEĆEM II, TUŽILAC PROTIV RADOSLAVA BRĐANINA, PRESUDA, 1. septembar 2004. paragraf 548. 104 Musić, R., 2001. Prijedor-sjećanje za nezaborav, Udruženje logoraša Bihać, Bihać, str. 113. 
strane Bošnjaka i Hrvata. ${ }^{105}$ Oni koji su ostajali bili su svakodnevno u opasnosti da budu ubijeni. ${ }^{106}$

Najčešće su konvoji išli pravcem Prijedor - Skender-Vakuf - Travnik, Prijedor - Bosanska Gradiška - R Hrvatska, Prijedor - Doboj. ${ }^{107}$ Nasilno protjerane osobe su najčešće transportovani kamionima i autobusima, ali bilo je transporta i vozovima. Sa željezničke stanice u Trnopolju vozovima su Bošnjaci i Hrvati transportovani u pravcu Doboja. Spiskovi i odobrenja za deportacije radila je SJB Prijedor kao i pratnju konvoja. Najveći broj Bošnjaka i Hrvata nasilno je protjeran u ljeto 1992. godine i to u periodu juni - septembar 1992. godine. ${ }^{108}$

Konvoji koje je organizovala srpska vlast opštine Prijedor kretali su s različitih mjesta i u različito vrijeme. Najčešće su konvoji kretali iz logora Trnopolje i sa stadiona u Tukovima. Ova kampanja nasilnog progona kontinuirano je trajala tokom 1992. i 1993. godine. Crveni krst opštine Prijedor je sačinjavao spiskove za iseljenje, a odobrenje je davala policija srpske opštine Prijedor. Logor Trnopolje je bio mjesto za masovno i nasilno protjerivanje nesrpskog stanovništva. Iz logora Trnopolje prema podacima opštinskog crvenog krsta Prijedor protjerano je 23.000 građana nesrpske nacionalnosti. ${ }^{109}$ Ovaj broj je potvrđen u suđenju pred MKSJ: "Kroz prihvatni centar Trnopolje našlo je smještaj 23.000 lica, a od tog broja smo sa Međunarodnim Crvenim krstom otpremili u prihvatni centar Karlovac 1.561 lice. Dana 29. septembra 1992. godine uz prisustvo evropskih promatrača ispraćen je konvoj za Karlovac." 110 Iz logora Trnopolje svakodnevno su odlazili konvoji sa Bošnjacima i Hrvatima. Najviše konvoja je išlo prema Travniku. Prema svjedočenju: "Edwarda Vulliamyja, britanskog novinara koji se 17. augusta 1992. pridružio jednom velikom konvoju automobila, autobusa i kamiona u kojima su bili ukrcani nesrbi, koji se

\footnotetext{
105 Sivac, N., 1995. Kolika je Prijedor čaršija, BONIK, Sarajevo, str. 221

106 Begić, 2015. str. 168.

107 ICTY, Predmet br. IT-97-24-A, PRED ŽALBENIM VIJEĆEM, TUŽILAC PROTIV MILOMIRA STAKIĆA, PRESUDA, 22. mart 2006, paragraf 815.

${ }^{108}$ Begić, 2015. str. 168.

${ }^{109}$ Isto, str. 168.

110 ICTY, Predmet br. IT-97-24-A, PRED ŽALBENIM VIJEĆEM, TUŽILAC PROTIV MILOMIRA STAKIĆA, PRESUDA, 22. mart 2006. paragraf 326.
} 
preko Banje Luke i Skender-Vakufa zaputio u Travnik. Konvoj je pratila naoružana policija, a dok su se vozili kroz brda, atmosfera je postajala sve više ispunjena nasiljem. On je izjavio: 'Posvuda su bili kamioni i ljudi koji su našem konvoju upućivali srpski pozdrav, te su ga pljuvali i vikali. A kad smo stigli u mjesto zvano Vitovlje, sjećam se da sam vidio ljude kako trče preko polja i bašti u tom selu i izvikuju nešto što znači (kako su mi rekli): 'Kolji ih, kolji ih'. Koristili su riječ, ja ne znam, jer ne poznajem jezik (...) koja se koristi za životinje, a ne za ljude." "111 U pojedinim konvojima je nasilno protjerivano više stotina Bošnjaka i Hrvata. ${ }^{112}$ U Obavijesti Crvenog krsta tzv. srpske opštine Prijedor broj 552/92 od 12. decembra 1992. godine obavještavaju se nadležne vlasti "da omoguće prolaz dole navedenim licima na relaciji: Bos. Gradiška-zona UNPROFOR-a do Novske, a preko Bos. Dubice." ${ }^{\text {113 }}$ Ovim konvojem 453 Bošnjaka i Hrvata su prisilno napustili općinu Prijedor i izbjegli u R Hrvatsku. Konvoji su kontinuirano iz Prijedora prevozili prisilno protjerane sve do 1996. godine. Ovi prisilni progoni pokazuju na kontinuitet $u$ etničkom čišćenju ovog prostora od nesrpskog stanovništva. Od 1993 do1996. godine u manjim grupama Bošnjaci i Hrvati su prisilno deportovani iz Prijedora. ${ }^{114}$ Odlasci iz Prijedora bili su u organizaciji Službe traženja Međunarodnog komiteta Crvenog Krsta i UNHCR-a. Za prolaz tih grupa Centar službe bezbjednosti Banja Luka i organizatori (MKCK i dr.) su od MUP-a RSK i SUP-a Okučani tražili dozvole za tranzit preko starogradiškog mosta i zapadne Slavonije. Izbjeglice su za prelaz morale imati dozvole

\footnotetext{
${ }^{111}$ Isto, paragraf 815.

${ }^{112}$ Begić, 2015. str. 170.

113 AIIZ, inv. br. 2-4699, Obavijest Crvenog krsta opštine Prijedor o prolazu konvoja, broj 552/92, od 12. XII 1992.
}

${ }^{114}$ Begić, 2015. str. 171. 
lokalnih vojnih i policijskih vlasti RS-a. ${ }^{115}$ Svi koji nisu imali te dozvole, vraćali bi s mosta natrag u Bosnu. ${ }^{116}$

U organizaciji MKCK, UNHCR-a i IOM-a (Međunarodna organizacija za migracije stanovništva) 23. jula 1993. je prošao konvoj od 50 Bošnjaka iz Ključa. Bili su to članovi obitelji bivših logoraša s Manjače koji su pušteni iz logora 1992. godine i otišli u inozemstvo, a sada su ovi članovi njihovih obitelji išli ka njima u inozemstvo, na spajanje obitelji. ${ }^{117}$ Isti takav konvoj s istim ciljem od 24 osobe iz Prijedora i 13 Bošnjaka iz Sanskog mosta je prošao 26. augusta 1993. ${ }^{118}$ Isti takav konvoj s istim ciljem od 36 osobe iz Prijedora je prošao 29. augusta

115 HMDCDR. Fond SUP Okučani. Kut. Miješana građa. Obavještenje MKCK o tranzitu 9 osoba iz Prijedora u Karlovac, od 17. VIII 1993., Depeša CSB Banja Luka SUP-u Okučani za saglasnost za prelaz 3 osobe iz Prijedora za Karlovac u organizaciji MKCK. Br: 11-1/01-591/93., od 25. VIII 1993., Depeša CSB Banja Luka SUP-u Okučani za saglasnost za prelaz 17 osoba iz Prijedora za Karlovac u organizaciji MKCK. Br: 11-1/01-630., od 2. IX 1993., Depeša CSB Banja Luka SUP-u Okučani za saglasnost za prelaz 19 osoba iz Prijedora za Gašince u organizaciji MKCK. Br: 11-1/01-686/93., od 21. IX 1993., Depeša CSB Banja Luka SUP-u Okučani za saglasnost za prelaz 20 osoba iz Prijedora i B. Gradiške za Gašince u organizaciji MKCK. Br: 11-1/01-724., od 28. IX 1993., Depeša CSB Banja Luka SUP-u Okučani za saglasnost za prelaz 17 osoba iz Prijedora i Bos. krajine za Zagreb u organizaciji MKCK. Br: 11-1/01-738., od 3. X 1993., Depeša CSB Banja Luka SUP-u Okučani za saglasnost za prelaz 16 osoba iz Prijedora za Zagreb u organizaciji MKCK. Br: 111/01-1022., od 20. XI 1993.

${ }^{116}$ HMDCDR. Fond SUP Okučani. Kut. Miješana građa. Sl. zabilješka SMON Okučani o pokušaju prelaza Suada Hubije iz G. Lipovače/B. Gradiška preko mosta na Savi, od 4. VI 1993.

${ }^{117}$ HMDCDR. Fond SUP Okučani. Kut. Miješana građa. Dopis MKCK o transferu 50 osoba iz Ključa. Br: 93/160., od 13. VII 1993., Depeša CSB Banja Luka SUP-u RSK za saglasnost za prelaz 50 osoba iz Ključa za Novsku u organizaciji MKCK. Br: 11-1/01-420., od 21. VII 1993.

${ }^{118}$ HMDCDR. Fond SUP Okučani. Kut. Miješana građa. Dopis MKCK o transferu 24 osobe iz Prijedora i Sanskog mosta. Br: 93/226., od 18. VIII 1993. 
1993. ${ }^{119}$ Isti takav konvoj s istim ciljem od 6 osobe iz Prijedora je prošao 23. novembra 1993. ${ }^{120}$

U zagrebačkom Večernjem listu stoji da je preko Crvenog križa 6. jula 1993. u Dragalić kod Nove Gradiške došlo 166 civila Hrvata i Bošnjaka iz Banjaluke, B. Gradiške i Prijedora, žena, djece i staraca. ${ }^{121}$

U svojim Izvještajima SJB Prijedor je izvještavao CSB Banja Luka o broju Bošnjaka i Hrvata koji su ostali u Prijedoru. Tokom 1993. godine obavljen je interni popis iz kojeg se vidi broj građana nesrpske nacionalnosti koji su ostali u Prijedoru. Kozarski vjesnik je 2. jula 1993. objavio članak pod naslovom "Ko smo i koliko nas je", u kojem su navedeni nezvanični rezultati popisa stanovništva za opštinu Prijedor, koji je izvršen nešto prije toga u sklopu popisa stanovništva u opštinama Republike Srpske. ${ }^{122}$ U tom članku navodi se "da su od 65.551 stanovnika u opštini, njih 53.637 pravoslavci, 6.124 muslimani, a 3.169 katolici. Pretresno vijeće je mišljenja da gore navedeni brojevi, koje odbrana nije osporila, pokazuju kako je užasavajuće efikasna bila kampanja deportacije nesrpskog stanovništva koju je potaknuo SDS. Ne samo da je ukupni broj stanovnika u opštini smanjen za gotovo $60 \%$, nego su i muslimanska i hrvatska nacionalna grupa desetkovane, i to za $87,6 \%$ odnosno 49,8\%. Novi popis stanovništva je pokazao da je opština Prijedor transformisana u praktično čisto srpsku opštinu sa 96,3\% srpskog stanovništva. ${ }^{123}$ Zajednički cilj stvaranja srpske opštine konačno je ostvaren." ${ }^{124}$ Bošnjaci i Hrvati koji su prisilno morali napustiti opšinu Prijedor prethodno su morali odjaviti boravište $u$ Prijedoru. Prema podacima SJB Prijedor broj prijava za odjavu

${ }^{119}$ HMDCDR. Fond SUP Okučani. Kut. Miješana građa. Depeša CSB Banja Luka SUP-u Okučani za saglasnost za prelaz 36 osoba iz Prijedora do Novske u organizaciji MKCK. Br: 11-1/01-443/93., od 27. VII 1993.

${ }^{120}$ HMDCDR. Fond SUP Okučani. Kut. Miješana građa. Depeša CSB Banja Luka SUP-u Okučani za saglasnost za prelaz 6 osoba iz Prijedora za Novsku u organizaciji MKCK. Br: 11-1/01-1041/93., od 23. XI 1993.

121 „Nastavlja se etničko čišćenje“, Večernji list, (Zagreb) br: 10.728., od 8. VII 1993. 122 Begić, 2015. str. 173.

${ }^{123}$ Isto, str. 173.

124 ICTY, Predmet br. IT-97-24-A, PRED ŽALBENIM VIJEĆEM, TUŽILAC PROTIV MILOMIRA STAKIĆA, PRESUDA, 22. mart 2006. paragraf 706. 
prebivališta bio je različit i svakim danom sve više Bošnjaka i Hrvata je podnosilo zahtjeve. Tako, "na dan 16.08.1992. godine SJB Prijedor je na zahtjev građana odjavila prebivalište za 13.180 građana koji su to zahtijevali u skladu sa pozitivnim zakonskim propisima."125 Prema podacima iz Izvještaja o radu SJB Prijedor za posljednjih devet mjeseci 1992. godine 17.167 osoba je odjavilo prebivalište radi iseljenja. ${ }^{126}$ Najprecizniji podatak o broju prisilno iseljenih Bošnjaka i Hrvata nalazimo u Izvještaju SJB Prijedor: “(...) U izvještaju MUP-a iz 1993. se navodi da se iz opštine Prijedor iselilo 42.000 Muslimana i 2.000 Hrvata, a doselilo približno 14.000 Srba. “"127

Konačno, krajem 1995. godine nasilno je protjeran još jedan broj Bošnjaka i Hrvata i u Prijedoru je ostalo oko 2.000 Bošnjaka i Hrvata ili 1,11\% od ukupnog broja po popisu iz 1991. godine.

\section{d) Opština Banja Luka}

Prema podacima iz popisa 1991. godine na području opštine Banja Luka živjelo je 195.692 stanovnika od toga 106.826 Srba (54,59 \%), Hrvata 29.026 (14,83 \%), Bošnjaka 28.558 (14,59 \%), Jugoslovena 23. $656(12,09 \%)$ i drugih $7.626(3,89 \%) .^{128}$

Po identičnom scenariju srpske vlasti i vojne i policijske jedinice postupale su kako bi raselili Bošnjake i Hrvate s prostora koje su privremeno okupirali. U tom smislu, kako se navodi u presudi MKSJ u predmetu Momčilo Krajišnik: "srpske opštinske vlasti i srpske snage stvarale su veoma teške životne uslove za Muslimane i Hrvate, koji su imali za cilj, i uspjeli, praktično onemogućiti većini Muslimana i Hrvata da ostanu. Preduzete mjere bi vremenom postajale sve drastičnije, počevši od otpuštanja s posla, pretraživanja kuća, isključivanja vode, struje i telefona. Nakon što bi srpske snage zauzele gradove i sela,

125 AIIZ, inv. br. 2-4688, SJB Prijedor, Izvještaj i prihvatni centri na području opštine Prijedor.

${ }^{126}$ AIIZ, inv. br. 2-4689, Izvještaj o radu SJB Prijedor za poslednjih 9 mj. 1992.

127 AIIZ, inv. br. 2-4692, CSB Banja Luka, Pregled odseljenih i doseljenih građana sa područja koji pokriva ovaj sektor, Banja Luka, maj 1993.

${ }^{128}$ Nacionalni sastav stanovništva, Rezultati za Republiku po opštinama i naseljenim mjestima 1991. Statistički bilten br. 234, Državni zavod za statistiku RBiH, Sarajevo, 1993. 
mnogi Muslimani i Hrvati su hapšeni i ispitivani, pri čemu su ih oni koji su ih uhapsili često mučili i tukli. Terorisanje muslimanskog i hrvatskog stanovništva često je uključivalo pojedinačna ubistva i pokolje, (...). Vijesti o takvim pokoljima dodatno su izazivale strah među muslimanskim i hrvatskim stanovništvom. Sve to je nagnalo mnoge Muslimane i Hrvate u opštinama poput Banje Luke, Bijeljine, Čelinca, Ilidže i Sanskog Mosta da, strahujući za svoju bezbjednost, napuste svoje domove." 129 Iz Banje Luke se kako „mnogi procjenjuju za devet mjeseci trajno iselilo više od 20.000 banjalučkih Muslimana. Uglavnom su preko Hrvatske otišli u zemlje zapadne Evrope. “130

Krajem 1995. godine na banjalučkom području je ostalo oko 2.000 Bošnjaka i Hrvata ili 1,12 \% od ukupnog broja po popisu iz 1991. godine. Ovaj broj je manji od $2 \%$ što je bilo predviđeno po planu koji je Radoslav Brđanin javno iznio.

\section{e) Ostale opštine}

Na području opštine Bosanski Petrovac prema popisu iz 1991. godine živjelo je 3.336 Bošnjaka i Hrvata. ${ }^{131} \mathrm{O}$ razmjerama nasilnih progona vidljivo je iz izvještaja CSB Banja Luka na području „RO Petrovac (Bosanski Petrovac, prim. M.B.) odseljeno: Muslimana 3.200, Hrvata 0, Srba 100. Doseljeno: Srba 4.000.“"132 Nakon što su jedinice 5. korpusa AR BiH oslobodile Bosanski Petrovac (14. septembra 1995. godine) zatekle su 10 građana nesrpske nacionalnosti ( 8 Bošnjaka i 2 Hrvata) ili $0,033 \%$ od broja po popisu iz 1991. godine.

${ }^{129}$ ICTY, Predmet br. IT-00-39-T, PRED PRETRESNIM VIJEĆEM I, TUŽILAC PROTIV MOMČILA KRAJIŠNIKA, PRESUDA, 27. septembar 2006. paragraf 729. ${ }^{130}$ Penava, Š., 2016. Kronologija, metode i etape etničkog čišćenja Hrvata i Bošnjaka na Banjalučkom području 1992-1996., Objavljeno u. Prešsćivani zločin - 20 godina pod teretom progona, nepravde i prešućivanja u RS-BiH, Zbornik radova, Banja Luka, str. 14.

${ }^{131}$ Nacionalni sastav stanovništva, Rezultati za Republiku po opštinama i naseljenim mjestima 1991. Statistički bilten br. 234, Državni zavod za statistiku RBiH, Sarajevo, 1993.

132 AIIZ, inv. br. 2-4692, CSB Banja Luka, Pregled odseljenih i doseljenih građana sa područja koji pokriva ovaj sektor, Banja Luka, maj 1993. 
Prema popisu iz 1991. godine na području opštine Bosanski Novi živjelo je 14.443 Bošnjaka i Hrvata. ${ }^{133}$ Srpske vojne i policijske snage su napale nebranjena naselja u kojim su živjeli Bošnjaci, protjerali ih i većinu zatvorili na stadion NK ,Bratstvo“ u Bosanskom Novom. Jedan broj je ubijen, a većina je nasilno protjerana i deportovana u pravcu Republike Hrvatske i Doboja. Bošnjaci s područja općine Bosanski Novi su 23. jula 1992. godine u konvoju autobusa i kamiona UNHCRa prisilno napustili grad. Jedan broj je potrpan u stočne vagone i nakon što su čitav dan u njima proveli bez vode $\mathrm{i}$ hrane protjerani su preko Doboja. U izvještaju CSB Banja Luka navodi se: „RO Novi Grad (Bosanski Novi, prim. M.B.) odseljeno: Muslimana 13.000, Hrvata 40, Srba nema podataka. Doseljeno: Srba 3.400.“134 Konačan progon Bošnjaka s područja Bosanskog Novog desio se u septembru 1995. godine. Prema podacima protjeranih u Bosanskom Novom nakon toga ostalo je da živi 200-300 Bošnjaka ili 0,4 \% od broja po popisu iz 1991. godine.

Na području opštine Bosanska Dubica po popisu iz 1991. godine živjelo je 6.928 Bošnjaka i Hrvata. ${ }^{135}$ Identično je bilo i u slučaju „Kozarska Dubica (Bosanska Dubica, prim. M.B.) odseljeno: Muslimana 4.500, Hrvata 400, Srba nema podataka. Doseljeno: Srba 2.500.“136 Krajem 1995. godine na području Bosanske Dubice ostalo su živjeti 642 osobe nesrpske nacionalnosti ili $0,43 \%$ od ukupnog broja. ${ }^{137}$

${ }^{133}$ Nacionalni sastav stanovništva, Rezultati za Republiku po opštinama i naseljenim mjestima 1991. Statistički bilten br. 234, Državni zavod za statistiku RBiH, Sarajevo, 1993.

134 AIIZ, inv. br. 2-4692, CSB Banja Luka, Pregled odseljenih i doseljenih građana sa područja koji pokriva ovaj sektor, Banja Luka, maj 1993.

${ }^{135}$ Nacionalni sastav stanovništva, Rezultati za Republiku po opštinama i naseljenim mjestima 1991. Statistički bilten br. 234, Državni zavod za statistiku RBiH, Sarajevo, 1993.

136 AIIZ, inv. br. 2-4692, CSB Banja Luka, Pregled odseljenih i doseljenih građana sa područja koji pokriva ovaj sektor, Banja Luka, maj 1993.

137 Bećirević, Z., Crni Dubički oktobar: Završna etapa etničkog čišćenja Bosanske Dubice: objavljeno na: https://www.bosnjaci.net/prilog.php?pid=68566 
Prema rezultatima popisa na području opštine Kotor-Varoš živjelo je 21.785 Bošnjaka i Hrvata. ${ }^{138}$ Na području opštine Kotor-Varoš masovni progon Bošnjaka i Hrvata bio je ,od lipnja do listopada 1992. godine

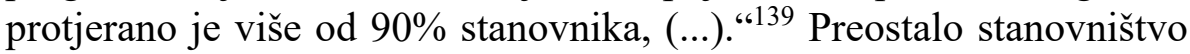
hrvatske nacionalnosti je konačno protjerano 27. augusta 1995. godine. ${ }^{140}$ Nakon zadnje faze progona na ovom prostoru ostalo je oko 1.000 osoba nesrpske nacionalnosti ili oko $2 \%$ od ukupnog broja po popisu iz 1991. godine.

Na području opštine Prnjavor gdje nije bilo borbenih djelovanja najveći broj Bošnjaka je nasilno protjeran. Prema podacima CSB Banja Luka iz „RO Prnjavor, odseljeno: Muslimana 2.053, Hrvata 923, Srba nema podataka. Doseljeno: Srba 2.500. ${ }^{141} \mathrm{U}$ augustu i septembru 1995. godine protjeran je najveći broj onih koji su ostali poslije progona 1992. godine.

Broj katolika - Hrvata u banjalučkoj biskupiji 1991. godine bio je 96.670, a 2014. godine 34.361 što je za 60.157 Hrvata manje u odnosu na 1991. godinu ${ }^{142}$ što najbolje pokazuje razmjere nasilnih progona $\mathrm{i}$ prisilnih deportacija.

\section{ZAKLJUČAK}

Prisilni progon i deportacije Bošnjaka i Hrvata s prostora Bosanske krajine dio su masovne, sistematične, planirane i organizirane kampanje, osmišljene od najviših srpskih političkih, vojnih i policijskih struktura. Ove nezakonite radnje nisu bile izolirani i pojedinačni slučajevi, nego smišljeni i planirani projekat. Ovaj projekat za krajnji

\footnotetext{
${ }^{138}$ Nacionalni sastav stanovništva, Rezultati za Republiku po opštinama i naseljenim mjestima 1991. Statistički bilten br. 234, Državni zavod za statistiku RBiH, Sarajevo, 1993.

139 Penava, 2016. str. 16.

${ }^{140}$ Isto, str. 18.

141 AIIZ, inv. br. 2-4692, CSB Banja Luka, Pregled odseljenih i doseljenih građana sa područja koji pokriva ovaj sektor, Banja Luka, maj 1993.

142 Puljić, V., 2016. Stanje katoličkih župa Vrhbosanske nadbiskupije na području Republike Srpske između 1991. i 2014. godine, Objavljeno u. Prešućivani zločin - 20 godina pod teretom progona, nepravde i prešućivanja u $R S$-BiH, Zbornik radova, Banja Luka, str. 219.
} 
cilj imao je masovni progon nesrpskog stanovništva koji je izražen u izjavi Radoslava Brđanina, predsjednika Skupštine ARK, koji kaže $d a$ je prihvatljiv postotak nesrba u srpskoj državi oko $2 \%$.

Prisilna premještanja i deportacije su dio ukupnih nastojanja trajnog uklanjanja Bošnjaka i Hrvata s prostora Bosanske krajine i nedvojbeno je “da je postojala smislena, dosljedna strategija etničkog čišćenja (podvukao. M. B.) koju je sprovodila policija bosanskih Srba i druge vlasti bosanskih Srba protiv bosanskih Muslimana i bosanskih Hrvata. Ova politika prisilnog premještanja bosanskih Muslimana i bosanskih Hrvata s tog područja provodila se raznim sredstvima po cijelom ARKu."143

U presudi MKSJ u predmetu Radoslav Brđanin navedeno je: "Pretresno vijeće se uvjerilo van razumne sumnje da su krivična djela počinjena u Bosanskoj krajini od aprila 1992. do kraja decembra 1992., odnosno u predmetno vrijeme Optužnice, izvršena kao direktna posljedica sveobuhvatnog Strateškog plana. Etničko čišćenje nije bilo popratni proizvod kažnjivih aktivnosti, nego je, naprotiv, bilo pravi cilj i stoga nerazdvojiv dio Strateškog plana. Isključiva namjera uvođenja uslova života nametnutih nesrpskom stanovništvu Bosanske krajine i vojnih operacija protiv gradova i sela koji nisu bili vojni ciljevi bila je da se ti ljudi otjeraju. Velik broj ljudi držan je u zatočeničkim centrima u užasnim uslovima. Budući da je namjera bila trajno ukloniti te ljude s teritorija Srpske Republike $\mathrm{BiH}$, mnogima su razoreni domovi kako se oni nikada ne bi vratili. Domovi bosanskih Muslimana koji nisu razoreni dodijeljeni su srpskim izbjeglicama iz Hrvatske i s drugih područja. Kampanja hotimičnog razaranja vjerskih i kulturnih ustanova bosanskih Muslimana i bosanskih Hrvata bila je samo jedan od elemenata šireg napada. Međutim, konačni cilj bio je uklanjanje stanovništva i uništenje njihovih domova. U augustu 1992. već je bilo očito da se takva diskriminatorska politika dosljedno primjenjuje. Dokazi otkrivaju dosljednu, koherentnu i kažnjivu strategiju čišćenja Bosanske krajine od drugih etničkih grupa koju su provodili SDS i snage bosanskih Srba. “144

${ }^{143}$ ICTY, Predmet br. IT-99-06-T, PRED PRETRESNIM VIJEĆEM II, TUŽILAC PROTIV RADOSLAVA BRĐANINA, PRESUDA, 1. septembar 2004. paragraf 548 ${ }^{144}$ Isto, paragraf 118. 
Kampanja srpskih vlasti, vojnih i policijskih snaga rezultirala je nasilnim progonom nekoliko stotina hiljada Bošnjaka i Hrvata iz okupiranih opština Bosanski Petrovac, Ključ, Sanski Most, Bosanski Novi, Prijedor, Banja Luka, Bosanska Dubica, Bosanska Gradiška, Bosanska Kostajnica, Kotor-Varoš, Prnjavor, dio opštine Bosanska Krupa, dio opštine Bihać.

\section{Izvori i literatura}

\section{Izvori}

Arhiv Instituta za istraživanje zločina protiv čovječnosti i međunarodnog prava Univerziteta u Sarajevu, više fondova.

Arhiv Hrvatskog memorijalno-dokumentacijskog centra Domovinskog rata, više fondova.

Arhiv Muzeja Unsko-sanskog kantona, Zbirka dokumenata, Bosanska krajina 1991- 1995.

Arhiv Instituta za nestale osobe Bosne i Hercegovine - Područni ured Bihać.

ICTY, Predmet IT-00-39\&40/1-S, PRED PRETRESNIM VIJEĆEM, TUŽILAC PROTIV BILJANE PLAVŠIĆ, PRESUDA, 27. februar 2003.

ICTY, Predmet br. IT-94-1-T, PRED PRETRESNIM VIJEĆEM, TUŽILAC PROTIV DUŠKA TADIĆA, MIŠLJENJE I PRESUDA, 7. maj 1997.

ICTY, Predmet br. IT-03-69-T, PRED PRETRESNIM VIJEĆEM I, TUŽILAC PROTIV JOVICE STANIŠIĆA, FRANKA SIMATOVIĆA, JAVNO SA POVJERLJIVIM DODATKOM C, PRESUDA, 30. maj 2013.

ICTY, Predmet br. IT-97-24-A, PRED ŽALBENIM VIJEĆEM, TUŽILAC PROTIV MILOMIRA STAKIĆA, PRESUDA, 22. mart 2006.

ICTY, Predmet br. IT-00-39-T, PRED PRETRESNIM VIJEĆEM I, TUŽILAC PROTIV MOMČILA KRAJIŠNIKA, PRESUDA, 27. septembar 2006.

ICTY, Predmet br. IT-02-54-T, TUŽILAC PROTIV SLOBODANA MILOŠEVIĆA, ODLUKA PO PRIJEDLOGU ZA DONOŠENJE OSLOBAĐAJUĆE PRESUDE, 16. juni 2004.

ICTY, Predmet br. IT-99-06-T, PRED PRETRESNIM VIJEĆEM II, TUŽILAC PROTIV RADOSLAVA BRĐANINA, PRESUDA, 1. septembar 2004. 
Nacionalni sastav stanovništva, Rezultati za Republiku po opštinama i naseljenim mjestima 1991., Statistički bilten br. 234, Državni zavod za statistiku Republike Bosne i Hercegovine, Sarajevo, 1993.

\section{Literatura}

Weiss, B., (2010) Nasljednici rata, Vrijeme, Zenica.

Begić, Kasim., (1997) Bosna i Hercegovina od Vensove misije do Dejtonskog sporazuma, Bosanska knjiga, Sarajevo.

Begić, M., (2017) Genocid u Sanskom Mostu, Institut za istraživanje zločina protiv čovječnosti i međunarodnog prava Univerziteta u Sarajevu, Sarajevo.

Begić, M., (2012) Genocid u Ključu, Institut za istraživanje zločina protiv čovječnosti i međunarodnog prava Univerziteta u Sarajevu, Sarajevo.

Begić, M., (2015) Genocid u Prijedoru, Institut za istraživanje zločina protiv čovječnosti i međunarodnog prava Univerziteta u Sarajevu, Hrvatskimemorijalno dokumentacijski centar domovinskog rata, Sarajevo, Zagreb.

Sivac, N., (1995) Kolika je Prijedor čaršija, BONIK, Sarajevo.

Musić, N., (2001) Prijedor - sjećanje za nezaborav, Udruženje logoraša Bihać, Bihać, 2001.

Čekić, S., (2012) Genocid i istina o genocidu u Bosni i Hercegovini, Institut za istraživanje zločina protiv čovječnosti i međunarodnog prava Univerziteta u Sarajevu, Sarajevo.

Čekić, S., (2007) Genocid u Bosni i Hercegovini na kraju dvadesetog stoljeća, uvodni referat na VII bijenalnoj konferenciji: Pravovremeno reagovanje na genocid: istraživanje genocida i njegova prevencija, Sarajevo, 9-13. jula 2007.

Penava, Š., (2016) Kronologija, metode $i$ etape etničkog čišćenja Hrvata $i$ Bošnjaka na Banjalučkom području 1992-1996., objavljeno u: Prešućivani zločin - 20 godina pod teretom progona, nepravde $i$ prešućivanja u RS-BiH, Zbornik radova, Banja Luka.

Puljić, V., (2016) Stanje katoličkih župa Vrhbosanske nadbiskupije na području Republike Srpske između 1991. i 2014. godine, objavljeno u: Prešućivani zločin - 20 godina pod teretom progona, nepravde $i$ prešućivanja u RS-BiH, Zbornik radova, Banja Luka. 
Mujo Begić, PhD

University of Bihac

Islamic Pedagogical Faculty

E-mail:mujo_begi@@hotmail.com

Ermin Vučkić, MA

Majlis IZ Kljuc

E-mail: erminvuckic@yahoo.com

\title{
VIOLENT PERSECUTION AND FORCED DEPORTATION OF BOSNIAKS FROM THE BOSNIAN KRAJINA AS A RESULT OF THE REPUBLIC OF THE SERB PEOPLE OF BOSNIA AND HERZEGOVINA PROCLAMATION IN BOSNIA AND HERZEGOVINA
}

\begin{abstract}
The result of the proclamation and activities of the Republic of the Serb People of Bosnia and Herzegovina is aggression and genocide committed by Serb military and police forces against Bosniaks. In the aggression against the Republic of Bosnia and Herregovina, the Serbian aggressor, with the use of superior military force, killed, wounded, destroyed their property, forcibly expelled them from their homes and forced them to permanently leave their homes and property. Forced relocations and deportations of Bosniaks and Croats from the territory of Bosnian Krajina were massive, systematic and planned, and were accompanied by killings, violence, various coercion, illegal detention, rapes, bombing and burning of houses, property robbery, and psychological pressure by Serb military and police units and civilian authorities. The goal of these persecutions and deportations was to reduce the non-Serb population in the territory of Bosnian Krajina to 2\%. In the period 1992-1995 several hundred thousand of non-Serbs were forcibly expelled from the Bosnian Krajina.
\end{abstract}

Key words: aggression, genocide, Bosnian Krajina, persecution, deportations 
الأستاذ المحاضر مويو بيغيتش

جامعة بيهاتش

كلية التربية الإسلامية

mujo_begic@hotmail.com

السيد الأستاذ أرمين وتشكيتش عضو في المشيخة الإسلامية بمدينة كليوتش erminvuckic@yahoo.com

\section{الاضطهاد العنيف والترحيل القسري للبوشناق من أراضي إقليم كرايينا البوسني

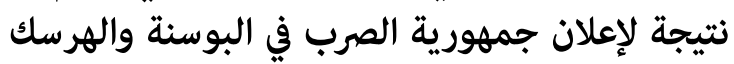

\section{الخلاصة}

كانت نتيجة إعلان جمهورية الصرب في البوسنة والهرسك هي الاعتداء والإبادة الجماعية التي

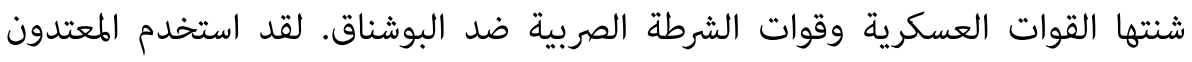

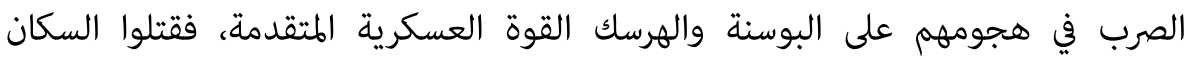

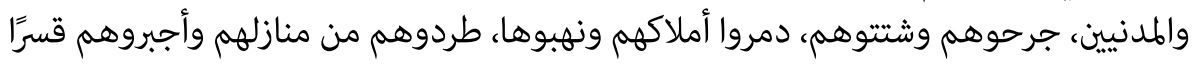
على ترك بيوتهم وممتلكاتهم بشكل دائم. كانت عمليات الترحيل القسري والتهجير الجماعي للبوشناق والكروات من منطقة إقليم

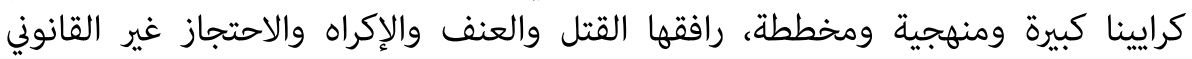

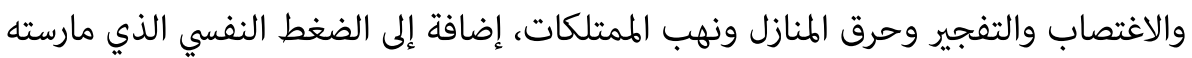

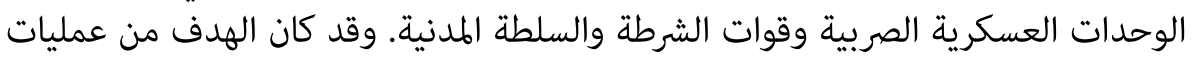

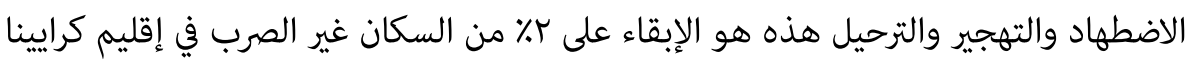

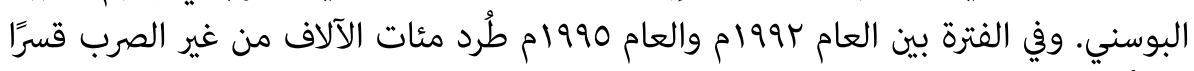
من أراضي إقليم كرايينا البوسني. الكلمات المفتاحية: اضطهاد، الإبادة الجماعية، إقليم كرايينا البوسني، تهجير، ترحيل. 